\title{
Unemployment Assistance and Transition to Employment in Argentina
}

\author{
Ana Iturriza ${ }^{\dagger}$ \\ Arjun S. Bedi * \\ Robert Sparrow ${ }^{\ddagger}$
}

September 2007

\begin{abstract}
In 2001-02, Argentina experienced a wrenching economic crisis. Plan Jefes, implemented in May 2002, was Argentina's institutional response to the increases in unemployment and poverty triggered by the crisis. The program provided a social safety net and appears to have successfully protected families against indigence. Despite this success, the continued existence of the program, which provides benefits to eligible unemployed individuals for an unlimited duration, may have unappealing long-term consequences. Reliance on the plan may reduce the incentive to search for work and in the long-run may damage individual employability and perpetuate poverty. Motivated by these concerns, this paper examines the effect of participating in Plan Jefes on the probability of exiting from unemployment. Regardless of the data set, the specification, the empirical approach and the control group, the evidence assembled in this paper shows that for the period under analysis individuals enrolled in the Plan are at least 20 percentage points less likely to transit to employment as compared to individuals who are not on the Plan. The negative effect of the program tends to be larger for females and as a consequence, over time, the program becomes increasingly feminized. Prima facie, the estimates suggest that programs such as Plan Jefes need to re-consider the balance between providing a social safety net and dulling work incentives.
\end{abstract}

JEL Codes: J64, J65

Keywords: Unemployment assistance programs, unemployment transitions, Argentina.

${ }^{\dagger}$ Buenos Aires, Argentina. ${ }^{\ddagger}$ Institute of Social Studies, The Hague, The Netherlands, and IZA, Bonn, Germany. We thank Admasu Shiferaw, Juan Ponce and an anonymous referee for helpful comments. Corresponding author: Arjun Bedi, Institute of Social Studies, Kortenaerkade 12, 2518 AX, The Hague, The Netherlands. Tel: 003170426 0493. Fax: 003170426 0799. Email: aiturr@yahoo.com.ar (A. Iturriza), bedi@iss.nl (A.S. Bedi), sparrow@iss.nl (R. Sparrow). 


\section{Introduction}

Since 1994, Argentina has experienced double-digit unemployment rates. Between 1993 and 2003 the number of unemployed workers doubled from about 1.1 million to 2.2 million workers translating into an increase in the unemployment rate from 9.6 to 15.6 percent, with a peak of 19.7 percent in 2002 (see Table 1).

Successive administrations in Argentina have used a variety of passive and active labor market interventions to protect workers against the consequences of unemployment. While there are several initiatives, at the moment the Argentinean system of unemployment compensation is dominated by a passive unemployment insurance (UI) program and an active unemployment assistance (UA) program called Plan Jefas y Jefes de Hogar Desocupados (Program for Unemployed Heads of Households), hereafter Plan Jefes.

The unemployment insurance (UI) program was created in 1991 and provides monthly income support to unemployed workers previously engaged in the formal sector and able to show contributions to the social security system. ${ }^{1}$ The amount of the benefit and the length of entitlement depends on individual labor histories and differs across individuals. The number of workers receiving benefits through this scheme peaked in 2002, surpassing 200,000 (see Table 2).

The gamut of active labor market programs includes job placement services, fiscal incentives for hiring firms and training programs for the unemployed. The largest program, Plan Jefes, has been in place since 2002. This program was the institutional

\footnotetext{
${ }^{1}$ Participation in the UI scheme is not voluntary. All individuals in the formal sector participate and contribute, excluding civil servants, agrarian workers and workers in domestic service (Law No. 24.013, National Employment Law).
} 
response to the explosive increase in poverty and unemployment that Argentina experienced at the end of 2001. In theory, it consists of a monthly allowance for eligible unemployed household heads. The benefit is granted on a flat-rate basis for an unlimited duration. To ensure that the program is self-targeted and reaches those who are most in need, a key aspect of the Plan is the requirement that participants provide a labour contribution (a counterpart of work) which typically assumes the form of a communitarian task.

A number of studies have analysed various aspects of the Plan Jefes program. For example, Roca et al. (2003), Galasso and Ravallion (2004), Franceschelli (2005) examine the targeting aspects of the program as well as its impact on poverty alleviation. Despite some leakage these papers confirm that the program did target the least skilled and the poor and that it protected individuals against poverty and indigence. ${ }^{2}$ While the program does seem to have had positive effects, the availability of benefits for an unlimited duration may have unintended and unappealing longer-term consequences. Reliance on the Plan may reduce the incentive to search for a job in the wider labour market and may damage individual employability, among other reasons, due to productivity deterioration (Pissarides, 1992) or statistical discrimination (Blanchard and Diamond, 1994). ${ }^{3}$ Accordingly, the availability of reliable estimates on the effect of Plan Jefes and more generally on the effect of unemployment assistance programs on the probability of

\footnotetext{
${ }^{2}$ According to Galasso and Ravallion (2004) about a third of those on the Plan did not satisfy the eligibility criteria. In terms of poverty alleviation they estimate that about $10 \%$ of the participants would have fallen below the food poverty line without the program.

${ }^{3}$ Galasso and Ravallion (2004) treat individuals providing counterpart work as employed and estimate that the program reduced the unemployment rate by 2.5 percentage points. However, as we argue in the following section, treating Plan individuals providing counterpart work as employed is inappropriate, especially as the work requirement is designed to help target the program.
} 
exiting unemployment are essential for the formulation of social policies that attempt to achieve an appropriate balance between social security and the provision of adequate job search incentives.

There is, of course, a large body of empirical literature on the effect of the benefit replacement rate (benefit elasticity) and duration of unemployment insurance/assistance programs (duration elasticity) on spells of unemployment. ${ }^{4}$ However, for obvious reasons, this body of work is largely restricted to the United States and European countries. ${ }^{5}$ Whether unemployment benefits finance longer unemployment periods and reduce the probability of exiting unemployment in the case of developing countries and Argentina in particular, is not clear. The large scale of Argentina's unemployment assistance program combined with scarce knowledge on the effects of such programs on job-search incentives (moral hazard) provides the motivation for our paper.

While the spirit of this paper is similar to the existing literature on the effect of unemployment insurance programs on unemployment duration, there are noteworthy differences. First, while we do study the effect of unemployment insurance, the main focus of the paper is on the effect of Plan Jefes. Second, the institutional arrangement of

\footnotetext{
${ }^{4}$ Surveys of this literature are provided, among others, by Atkinson and Micklewright (1991), Holmlund (1998) and Meyer (2002). While the magnitude of the elasticities varies across countries, in general, consistent with theory, there is evidence of disincentive effects associated with unemployment insurance/assistance.

${ }^{5}$ According to Meyer (2002), evidence on the effect of UI programs appears to be more robust for the United States as opposed to Europe. According to him, in the case of the United States, a benefit elasticity of 0.5 is not an "unreasonable rough summary". Duration elasticity estimates tends to be lower with estimates ranging from 0.1-0.4 (Meyer, 1990; Katz and Meyer, 1990; Card and Levine 2000). Studies based on Western and Eastern European countries report a wider range. For example, Carling et al. (2001) examine data before and after a benefit cut in Sweden and find a benefit elasticity of 1 . At the other extreme, Lubyova and van Ours (1998) find that there are no disincentive effects associated with the Slovak benefit system. Estimates for other countries tend to lie between this range. Recent studies, such as Jenkins and Garcia-Serrano (2004) report a benefit elasticity of 0.2 for Spain, Roed and Zhang (2005) estimate a benefit elasticity of 0.6 for Norway.
} 
the program under scrutiny is different from the system prevailing in a number of developed countries. In Argentina, large fiscal deficits have limited the generosity of the unemployment assistance program. Faced by a tradeoff between coverage and replacement rate, the Jefes program favors the former and provides a monthly benefit of Pesos 150 (a rate below the minimum wage) to all beneficiaries for an unlimited duration. ${ }^{6}$ This is unlike the unemployment insurance/assistance programs examined in the bulk of the empirical literature which tend to provide a relatively higher level of benefits for a limited duration. Third, consistent with the design of the Jefes program, we do not estimate duration and benefit elasticities but examine the effect of participating in Plan Jefes on the probability of exiting to employment. ${ }^{7}$

To preview our results, we find that, regardless of the data set, the specification or the empirical approach, individuals enrolled in the Plan are far less likely to transit to employment as compared to individuals who are not on the plan. This result holds regardless of whether Plan participants are compared to all non-Plan participants or whether the comparison is restricted to those who applied for the Plan but do not receive benefits. The effects of the program are gender sensitive. Program participation exerts a much stronger negative effect on the probability of transiting to employment for females, and as a consequence, over time, the program becomes increasingly feminized. Prima facie, the estimates support the idea that by reducing unemployment costs and thereby

\footnotetext{
${ }^{6}$ According to the National Council of Employment, Productivity and Minimum Wages, Resolution No. $2 / 93$, the minimum wage was Pesos 200 per month at the time that Plan Jefes was implemented.

${ }^{7}$ In principle we could estimate the effect of Plan Jefes on the duration of unemployment. While information on the duration of unemployment for those who are still unemployed is reliable, information for those who have transited to employment yielded a large number of inconsistencies. Rather than providing information on how long they had been working in their current job the respondents appeared to be providing information on the duration spent in their current occupation.
} 
increasing reservation wages and reducing job-search intensity the Plan reduces the probability of transiting to employment. Alternative explanations for the reduced probability of transiting to employment are also discussed.

The paper is organized in the following manner. Section II provides additional information on the unemployment insurance and assistance systems. Section III describes the data and presents descriptive statistics. Section IV presents an empirical framework tailored to the problem and data at hand. Section V presents the empirical findings while the final section summarizes and concludes the paper.

\section{Unemployment and unemployment benefits}

Argentina has experienced sharp increases in unemployment and underemployment rates in the 1990s. As displayed in Table 1, unemployment rose from a low of 6.5 percent in 1991 to a high of almost 20 percent during the economic crisis. While the recent recovery of the economy has been accompanied by a decline in unemployment, the rate still hovers between 10 to 12 percent, considerably higher than the rate at the beginning of the 1990s. The quality of jobs, as measured by the underemployment rate and the degree of informal sector work has also declined. ${ }^{8}$ While 9.4 percent of the employed were classified as underemployed in the early 1990s, the figure was about 22 percent in 2003. During the same period, the percentage of workers employed outside the regulated market rose from 30 to 45 percent. The decline in the quantity and quality of employment is reflected in the sharp increase in the incidence of poverty. ${ }^{9}$

\footnotetext{
${ }^{8}$ Individuals who work less than 35 hours per week and would like to work more are treated as underemployed while workers that do not contribute to the retirement system are treated as informal sector workers.

${ }^{9}$ For example, in Metropolitan Buenos Aires, the incidence of poverty rose from 17.6 in 1994 to 51.7 in 2003 (see Franceschelli, 2005).
} 


\section{II.1 Unemployment Insurance}

The increase in unemployment since the 1990s has usually been interpreted in the context of economic reforms initiated at the beginning of the 1990s. These reforms included privatization, deregulatory and trade-openness policies. In the labor arena, reforms were aimed at creating a more flexible labor market (Lanari, 2003) and included measures to reduce the costs of layoffs and encourage short term contracts (Campos, 2000). In anticipation of the increase in unemployment, the government introduced limited duration unemployment insurance at the end of 1991. According to the Employment Law of 1991, the UI scheme was introduced as the legal mechanism to "regulate the impact of the processes of productive conversion and structural reforms on employment". Thus, UI was introduced in a labor market characterized by the absence of protection for unemployment and at a time when increases in unemployment were seen as inevitable.

In terms of eligibility, unemployment insurance may be accessed by unemployed workers who have contributed to the scheme for at least six months during the three years preceding unemployment. The level of benefits is determined by a Council of Productivity, Employment and Minimum Wage and is based on the highest net wage earned in the six months preceding unemployment. The duration of entitlement depends on the time period and level of contributions and ranges from 2 to 12 months. In addition to searching for jobs while receiving benefits, recipients are obliged to accept jobs offered by the labor authority.

The UI system offers limited protection to workers. Since its introduction, the share of unemployed receiving insurance has remained between 5 and 7.5 percent (Social 
Security Secretariat, www.seguridadsocial.gov.ar). While exclusion has been observed in countries with a longer history of unemployment insurance, Argentina also displays a high level of exclusion. ${ }^{10}$ The system excludes informal workers and regardless of their legal status, several categories of workers such as domestic workers and self employed are also excluded from participation (Roca et al., 2003). Thus, similar to the situation in other Latin American countries, UI is an instrument of limited scope that does not provide benefits to the poorest (Samaniego, 2002). In general, the scheme benefits middle-income salaried workers (Mazza, 2000).

\section{II.2 Unemployment Assistance}

Ten years after the introduction of the UI scheme, in the context of a severe economic crisis, the government introduced an unemployment assistance scheme, called Plan Jefes. The plan was the institutional response to the increase in poverty and unemployment triggered by the crisis. The decree accompanying the creation of the scheme declared that the Plan aims to "guarantee the right to social inclusion to all Argentinean families" (Decree No. 565/2002). The program was signed into law in April 2002 and between April 4 and May 17, 2002, individuals could apply and register for the program. Individuals who met the eligibility conditions were issued social security cards and registered in a national data base (for more details see Tcherneva and Wray, 2005). For

\footnotetext{
${ }^{10}$ Based on data from the 1990s, Meyer (2002) reports that in the United States 97 percent of all wage and salary workers are in jobs covered by UI. However, less than 40 percent of the unemployed actually received UI.
} 
the most part, individuals who did not register by May 17 were unable to join the program. $^{11}$

The scheme is targeted at less-skilled unemployed workers and the objectives of the program are to provide a short-term safety net while at the same time increasing employability through training activities. In terms of statutory requirements, the scheme is restricted to unemployed household heads (implicitly, one person per household) with children aged 18 or less or those with handicapped children irrespective of age. ${ }^{12}$

To ensure self-targeting, Plan benefits were set below the minimum wage and all participants receive the same benefit of Pesos 150 a month for an unlimited duration. In addition, individuals enrolled in the scheme are expected to search for jobs while at the same time they are expected to carry out one or more of the following activities (i) complete formal education or engage in training activities (ii) provide a labor (counterpart work) contribution of up to 20 hours a week for communitarian activities such as maintenance and construction of social infrastructure, cleaning of public spaces, sanitary and health supporting activities, childcare (Roca et al., 2003) (iii) perform administrative tasks in local agencies or work in enterprises associated with the Plan.

In contrast to the UI program, the UA scheme is inclusive. Since 2002, the scheme has provided benefits to about 1.5-1.9 million individuals per year or about 13 to 15 percent of the labor force. Total expenditure on the Plan amounts to about 1 percent of GDP (Tcherneva and Wray, 2005). Most of the Plan participants (about 84 percent)

\footnotetext{
${ }^{11}$ According to Tcherneva and Wray (2005) "The program is designed to limit entry to those who had qualified and signed-up by May 17, 2002, although some who did not meet the deadline have been added. This is said to have resulted in some cases of discrimination because other potential participants were denied access even though they appeared to meet program requirements-but had missed the deadline."

${ }^{12}$ Individuals who receive unemployment insurance, a pension, or are employed even in the informal sector, are not allowed to participate.
} 
are engaged in communitarian activities and contributing 20 hours of labor under the aegis of Plan is their primary labor market activity (Ministry of Labor, Employment and Social Security (MTESS), 2004).

While the Plan was intended for unemployed heads of household, in practice, these requirements were not fulfilled. Administrators did not ensure that applicants were really heads of households and nor is it clear that only the unemployed were admitted into the Plan. Anecdotal evidence as well as formal analysis in Galasso and Ravallion (2004) shows that many Jefes participants, almost exclusively women, were inactive before joining the program. The implications of this, for our analysis, are discussed later on in the text.

\section{II.3 Measuring unemployment}

Conventionally, official statistics in Argentina treat beneficiaries of social plans who contribute any type of labor as employed. In the case of Plan Jefes, the inadequacy of applying this definition was noted at the outset. The labor or counterpart work requirement of the Plan was introduced to ensure self-targeting and should not be viewed as employment. In fact, the requirement that most Plan participants should be providing a labor contribution was a condition for World Bank financing (Galasso and Ravallion, 2004). An application of the conventional definition, given the scale of Plan Jefes and the condition that a large proportion of beneficiaries should and indeed do provide 20 hours of labor, would lead to an extremely misleading picture of the country's level of unemployment. Furthermore, the Plan is intended to provide a short-term social safety net for the unemployed and Plan beneficiaries are expected to search for alternative jobs. 
In such circumstances treating those who provide a labor contribution as employed is clearly not suitable.

Official statistics have been adapted to distinguish between employment derived from the Plan (assisted employment) and other employment (unassisted employment). As a result, the Argentinian Bureau of Statistics (INDEC) periodically presents different sets of labor market indicators, based on alternative classifications of beneficiaries. ${ }^{13}$ In this paper, we treat individuals that report the Plan as their main activity as unemployed. Those who are in training are considered inactive while those who work in local agencies or in enterprises associated with the Plan and for whom the Plan is a secondary activity, are considered as employed.

\section{Data}

\section{III.1 Data}

The analysis conducted in this paper is based on three rounds of data collected under the auspices of the Permanent Household Survey (EPH) by INDEC. The EPH is an urban household survey, which till 2003 was conducted twice a year, usually in May and October. The survey is conducted in provincial capitals and areas with a population of more 100,000. It covers 28 urban agglomerates and represents about 61 percent of the country's population (INDEC, 2001). ${ }^{14}$

The survey has a rotating panel structure with 25 percent of households replaced in each round. The May and October 2002 covered about 50,000 individuals in the

\footnotetext{
${ }^{13}$ INDEC computes three different unemployment figures. The first or the General level treats all Plan participants as employed. The second definition treats participants with Plan as their main activity and looking for a job as unemployed and finally, the third definition treats all participants with Plan as their main activity as unemployed.

${ }^{14}$ According to the 2001 Census, about 90 percent of Argentina's approximately 36 million people live in urban areas. In October 2002 the survey was extended to cover three more urban agglomerations.
} 
working age population (16-64) while the May 2003 sample was smaller and covered around 37,000 individuals. In principle, based on the sample design and in the absence of sample attrition, of the households sampled in May 2002, 75 percent should still appear in the October 2002 survey, while 50 percent should appear in the May 2003 survey.

The survey contains detailed information on a variety of household and individual characteristics, including information on employment, incomes, household demographics, housing, and education. From the point of view of this paper, the key data contained in these surveys is the availability of information on the employment experience of individuals. The surveys collect information on the labor market status of individuals (employed, unemployed, inactive), whether they receive unemployment benefits (insurance or assistance) whether they have applied for unemployment assistance and the date at which they started receiving unemployment benefits.

Plan Jefes was implemented in April-May 2002 and the October 2002 survey contains information on Plan participation. The survey also elicits information on the date that individuals who receive unemployment benefits started receiving such benefits. This allows us to determine whether an individual has been receiving benefits since May 2002. We are, thus, able to observe the labor market status as well as unemployment benefits status of individuals in May 2002, October 2002 and May 2003. We cannot go beyond this survey as several aspects of the EPH changed after May 2003, making it impossible to merge information across additional surveys. ${ }^{15}$ Accordingly, the analysis

\footnotetext{
${ }^{15}$ Since May 2003 the frequency of data collection has been increased to four times a year and a new questionnaire has been created. Among other reasons, the new questionnaire is designed to capture irregular employment. The changes in the questionnaire and in some of the definitions make it difficult to merge data sets collected using the two different questionnaires.
} 
presented in the paper is based on merging information contained in the May 2002, October 2002 and May 2003 rounds of the EPH.

Information contained in the three individual data sets are used to create two panels. The first of these covers a 12 month period and combines information contained in the May 2002, October 2002 and May 2003 surveys. The second combines information from the October 2002 and May 2003 data sets. The one-year panel allows us to observe the labor market status of individuals at three points in time but it has fewer observations, while for the shorter six month panel we have a larger number of observations but can observe transitions only between October 2002 and May 2003. Restricting ourselves to individuals in the working age population (aged 16 to 64) yielded 12,576 common observations for the period covering May 2002 to May 2003 and 22,947 common observations for the period October 2002 to May $2003 .{ }^{16}$

Based on the sample design and adjusting for the smallest sample (May 2003), we expected about 18,000 observations in the longer panel and about 27,750 in the shorter panel. While the actual numbers fall short of these expected figures by about 5,2505,500 , there does not seem to be a systematic difference between the individual data sets and the merged panels. For example, for all three surveys and for the two merged panels the gender and educational compositions of the data sets do not show much variation (see

\footnotetext{
16 The May 2002 survey contained 50,712 observations, the October 2002 survey contained 50,782 observations while the May 2003 survey contained 37,510 observations. Merging three rounds of the survey yielded 12,576 observations. Of these 1429 observations were dropped due to inconsistencies in information on gender and age, yielding a total of 11,147 observations. Analogously, an initial merger of two rounds of the survey yielded 22,947 observations, which fell to 21,292 after dropping observations with inconsistencies in the gender and age variables.
} 
Table A1). Overall, these comparisons suggest that despite the smaller than expected sample size the merged data sets are not unduly influenced by sample attrition. ${ }^{17}$

The focus of our analysis is on unemployed individuals and in the 12 month panel there are 1,455 individuals who were unemployed at the beginning of the period. These individuals may be divided into four categories. The first category consists of those who do not receive any unemployment benefits (69 percent). The second category includes those who were enrolled in the Plan in May 2002 (about 23 percent). ${ }^{18}$ The third category comprises individuals who have applied for the Plan but do not receive benefits (about 6.5 percent). The Plan limited entry to those who had qualified and enrolled by May 17, 2002, thus, there is a set of individuals who have applied for the Plan and who may meet the program's requirements but at the time of the survey were still awaiting the decision of the labor authorities. ${ }^{19}$ The availability of individuals who fulfill the requirements of the Plan and have applied for it, provides a control group that is potentially similar in terms of observed and unobserved characteristics to those who do join the plan. The fourth category consists of individual who have access to

\footnotetext{
${ }^{17}$ Support for the idea that attrition does not exert a large effect on EPH panels is provided by Cruces and Wodon (2002) and McKenzie (2004). Based on EPH data covering the period May 1995 and May 2002, Cruces and Wodon (2002) argue that attrition in the EPH panel does not affect income trends. McKenzie (2004) reports that panels constructed before and after the economic crisis should not be substantially affected by attrition.

${ }^{18}$ The number of Jefes participants as a percent of unemployed obtained from the survey data is quite different from the corresponding figure based on administrative data. There could be several reasons for this. Foremost, among these is that the survey data covers 61 percent of the population while administrative data are for the whole country. The survey data refer to individuals who are on the Plan while the administrative data refer to number of Plans in a calendar year. If an individual exits and reenters the Plan then the administrative data treats this as two plans. While it seems that the survey data underrepresents Plan participation, according to a comparative analysis carried out by Galasso and Ravallion (2004), the discrepancies are not "large enough to warrant serious concern about sampling bias".

${ }^{19}$ While, some of the applicants were eventually allowed to enroll in the Plan, for the most part access was denied. Of the 95 individuals who were applicants in May 2002, 19 were subsequently accepted in the Plan, while of the 207 applicants in the 6 month panel, 32 were eventually accepted in the Plan. The estimates presented in the paper are robust to the exclusion of the individuals who change their Plan status.
} 
unemployment insurance (1.8 percent). In the 6 month panel there are 3,161 individuals and of these about 60 percent do not receive any benefits, 31 percent are on the Plan, 6.5 percent have applied for the Plan but do not receive any benefits and the remaining 2 percent receive UI benefits.

\section{An analytical framework}

\section{IV.1 Theoretical Responses to Plan Jefes (Unemployment Benefit Schemes)}

While unemployment compensation schemes are expected to exert several influences on the labor market behavior of individuals (see Meyer, 2002 and Vodopevic, 2004), the bulk of the literature focuses on the effect of unemployment compensation schemes on the probability of re-employment and the time spent out of work. Static labor supply models (for example, Moffitt and Nicholson, 1982) as well as job-search models (such as Mortensen, 1986) have been used to examine the effect of unemployment insurance/assistance schemes on the probability of re-employment and duration of unemployment. Both approaches predict that individuals enrolled in unemployment schemes are less likely to exit to employment and that enrollment in schemes with a higher replacement ratio and a longer duration of benefits prolongs unemployment spells. $^{20}$

Invoking a job-search model and based on our knowledge of the organization of Plan Jefes, consider an unemployed worker searching for jobs in a decentralized labor market. In the spirit of Mortensen $(1977,1986)$ and Meyer (2002) assume that this

\footnotetext{
${ }^{20}$ Although it is the dominant prediction in the literature, the argument that unemployment compensation schemes necessarily reduce the probability of exiting unemployment is by no means a foregone conclusion. An alternative argument, which runs counter to the predictions of the job-search models, is that by subsidizing the costs of searching for a job, unemployment compensation systems encourage greater jobsearch intensity which raises the rate at which acceptable job offers arrive thereby increasing the probability of exiting unemployment (see Duncan 2002).
} 
worker chooses a job-search intensity $(s)$ and a minimally acceptable (reservation) jobquality $(q)$, which for simplicity may be thought of as a function of the minimum wages and minimum job tenure sought by the unemployed worker. For a given job-search intensity the workers face a known job-quality offer distribution and a constant probability of receiving job offers, $(\lambda(s))$. The probability of exiting unemployment may be defined as $\lambda(s)[1-F(q)]$, where $F$ is the cumulative distribution function of job-quality offers. If an unemployed worker is offered a job at a quality that exceeds the reservation job-quality, it is accepted, and she transits to employment.

Given this set up let us consider the effect of Plan Jefes. Individuals enrolled in Plan Jefes receive monthly monetary payments which are set at a level below the minimum wage for an unlimited duration of time. Although Plan benefits may be low, given the unlimited duration of benefits (security of tenure as long as the program lasts), and the expectation of additional benefits, Plan participants clearly face a lower cost of being unemployed (higher cost of exiting to employment) as compared to nonparticipants. ${ }^{21}$ Accordingly, Plan participation may be associated with reduced search intensity, increases in reservation job-quality and a lower probability of exiting to employment. More explicitly, this discussion yields two clear predictions. First, Plan participants should have a lower probability of exiting to employment as compared to non-participants and second, the quality of jobs accepted by Plan participants should be higher than the quality of jobs accepted by non-participants.

\footnotetext{
${ }^{21}$ Although it does not apply to the period under analysis the Plan does provide additional benefits. In December 2003 a one time grant of Peso 50 was provided to all participants. Since June 2004, Plan participants are entitled to a 15 percent discount on expenditure in shops associated with the plan. In addition, they are also entitled to a 3.15 percent reduction in the VAT (decree 682/04 and Law 25.921).
} 
Plan Jefes participants receive the same benefits for an unlimited duration of time. The benefits were fixed at the commencement of the program and are not indexed to inflation. Thus, the real value of benefits declines over time. Over time, the erosion of Plan benefits should lead to an increase in the cost of being unemployed which in turn should enhance search intensity, reduce reservation job-quality and lead to an increase in the probability of transiting to employment. ${ }^{22}$ Even without inflation, an increase in the transition rate over time is consistent with the argument that the availability of unemployment benefits allows recipients to search for a better job match. Since recipients may not be forced to accept the first job they are offered, after an initial period of low transition their probability of exiting to employment may increase. Thus, the third prediction yielded by this framework is that, over time, Plan participants should display a greater probability of exiting to employment.

The empirical work presented in the paper examines two of these three predictions, namely, whether Plan participation reduces the probability of exiting to employment and whether the probability of exiting to employment increases over time. Apart from information on the monthly wages of the jobs to which individuals transit we do not have much information on job quality and accordingly, the expectation that individuals on the plan transit to higher quality jobs is not examined in detail.

\section{IV.2 Empirical strategy and specification}

The main empirical challenge in the paper is to isolate the effect of Plan Jefes on the probability of exiting unemployment, after controlling for various other factors that

\footnotetext{
${ }^{22}$ Between May 2002 and October 2002, inflation was 11.2 percent while it was 2.86 percent between October 2002 and May 2003.
} 
may influence job-search intensity and reservation job-quality. Accordingly, the probability of exiting to employment, $P\left(Y_{i}=1\right)=(\lambda(s)[1-F(q)])$, is treated as a function of observed characteristics that influence job-search intensity $(s)$ and reservation job quality $(q)$, that is,

$P\left(Y_{i}=1\right)=G\left(\beta_{0}+\beta_{U I} U I+\beta_{P J}\right.$ Plan Jefes $\left.+\beta_{A} A+\beta_{I} I+\beta_{H} H H+\beta_{L M} L M\right)$.

Several variants of (1) are estimated as a logit model. UI and Plan Jefes indicate whether an individual receives unemployment insurance benefits or benefits through Plan Jefes, respectively. Individuals who have applied to Plan Jefes but do not receive any benefits are categorized as applicants $(A)$. The reference category consists of those who do not receive any type of unemployment benefits and have never applied for benefits. I and $H H$ are individual characteristics (gender, age, marital status, education), household demographic (family size, number of children younger than 14, number of earning household members) and wealth characteristics (access to water and electricity, type of dwelling, household density), respectively. $L M$ is a set of labor market characteristics. These characteristics include regional fixed effects, a variable that indicates whether an individual had any job experience prior to being unemployed, information on whether the contract for the job held just prior to being unemployed was temporary, ad-hoc or permanent, whether the individual was a wage employee or self-employed, and indicators for the size of firm of an individual's last job.

In (1), the effect of Plan Jefes on transiting to employment is compared with the transition rate of non-participants. Despite controlling for a number of characteristics, it is possible that comparisons between Plan participants and non-participants are not appropriate. The available data contains information on individuals who have applied for 
the Plan but do not receive benefits. Since applicants may have been eligible to join the Plan, on average, they are likely to have observed characteristics that are similar to those on the Plan. ${ }^{23}$ Furthermore, since these individuals have applied for the plan and have indicated a preference for program participation, it is possible that, on average, their unobserved characteristics are similar to the unobserved characteristics of Plan participants. $^{24}$ Thus, we estimate a second set of logit models where applicants are treated as the appropriate control group and the estimation is restricted to Plan participants and applicants, that is,

$P\left(Y_{i}=1\right)=G\left(\beta_{0}+\beta_{P J}\right.$ Plan Jefes $\left.+\beta_{I} I+\beta_{H} H H+\beta_{L M} L M\right)$.

These logit models control for observables, however, they impose a specific functional form on the relationship between Plan participation and the probability of transiting to employment. An alternative approach relies on propensity score matching to control for observable heterogeneity between Plan participants and nonparticipants/applicants. Plan participants are matched to observationally similar nonparticipants/applicants and thereafter the average treatment effect (on the treated) of Plan participation on employment transitions is computed.

Let $P J_{i}$ indicate participation in Plan Jefes. Following Rosenbaum and Rubin (1983), propensity scores, that is, $\operatorname{Pr} o b\left(P J_{i}=1 \mid X_{i}\right)$, are obtained from a logit regression

\footnotetext{
${ }^{23}$ While the group of applicants may be a better control group as compared to non-participants who did not apply for the program, it is possible that these applicants experienced different conditions (for example, lower income shocks) as compared to those who applied on time or they were uncertain about satisfying the program's eligibility conditions. To address concerns about differences in observable characteristics we continue to estimate models that control for a full set of observed characteristics.

${ }^{24}$ This pipeline comparison designe has been used, among others, by Angrist (1998), Chase (2002), and Galasso and Ravallion (2004). Despite the use of an applicant control group, the possibility that unobserved characteristics between applicants and Plan Jefes participants continues to exist cannot be ruled out. However, as pointed out later in the text, such issues may not have a large bearing in the current case.
} 
of Plan participation on observed characteristics $\left(X_{i}\right)$. The average treatment effect on the treated (ATT) when $N$ Plan Jefes participants are matched to $C$ non-participants $(N P)$ may be written as,

$$
A T T=\frac{1}{N} \sum_{i=1}^{N}\left(Y_{i}^{P J}-\sum_{j=1}^{C} W_{i j} Y_{j}^{N P}\right)
$$

Similarly, the ATT when Plan participants are matched to applicants $(A)$ may be written as,

$$
A T T=\frac{1}{N} \sum_{i=1}^{N}\left(Y_{i}^{P J}-\sum_{j=1}^{C} W_{i j} Y_{j}^{A}\right) .
$$

$Y_{i}$ indicates the outcome for each of the different groups and $W_{i j}$ are the weights that are used to calculate the counterfactual outcome for each Plan participant. Provided that unobserved characteristics of Plan participants and applicants are similar, the ATT provides an unbiased estimate of the effect of Plan Jefes on employment transitions. The ATT is estimated using five nearest-neighbor and kernel matching and the estimates are restricted to the region of common support.

Both the approaches outlined here control for differences in observed characteristics and rely on the assumption that using a control group that has applied for the Plan is likely to deliver unbiased estimates of the effect of the Plan on transiting to employment. In their work on evaluating the effect of Plan Jefes on various outcomes, Galasso and Ravallion (2004) also use matching methods to create a control group from a sample of applicants. Thereafter, they compute the ATT of Plan Jefes on various outcomes using a single-difference estimator and a double-difference estimator. In our case, since we follow individuals with the same outcome at the start of the period (they are all unemployed), the single- and double-difference estimators do not differ. While the 
double-difference estimator controls for differences in time-invariant unobservables, Galasso and Ravallion (2004) treat the single-difference estimates as their preferred results. Additionally, for most of the outcomes their single- and double-difference estimators yield similar results, suggesting that the use of applicants as a control group mitigates concerns about the effect of unobserved characteristics. Nevertheless, in the spirit of a sensitivity analysis we do attempt to control for the effect of unobservables using selection models. ${ }^{25}$

The two-state models discussed so far ignore the probability that individuals may also transit to inactivity. While focusing on the two-states is similar to the approach adopted in the bulk of the empirical literature, a more complete picture of unemployment transitions should be concerned not just with transitions to employment but also transitions to inactivity. ${ }^{26}$ Given the aim of this paper it is crucial to examine the effect of the Plan on transitions to employment after controlling for its effect on inactivity. As may be anticipated, the Plan attracted individuals who were previously inactive and declared themselves as active and unemployed in order to access Plan benefits. Ignoring

\footnotetext{
${ }^{25}$ While impeded by the availability of variables (good instruments) that may exert a strong and exclusive influence on Plan participation and not influence the probability of finding a job, in the spirit of a sensitivity analysis we endogenize program participation and estimate a program participation probit model which is used to compute generalized residuals (see Vella, 1993). These generalized residuals are included in probit estimates of the probability of transiting to employment to control for selection effects associated with program participation.

${ }^{26}$ The possibilities available to model transitions depend on the characteristics of the dataset available for analysis. While panels based on household surveys generally provide complete information regarding flows among employment, unemployment and inactivity, other sources of data like UI and UA registers limit themselves to recording entries and exits from the register, and may not record information on transitions out of the labor force. Much of the literature on unemployment compensation originated in countries with well developed protection systems and relies on the second type of data to model unemployment compensation and hence excludes inactivity from the analysis. For Argentina a series of papers focus on the two-state model to analyze transitions in the labor market. These include, Arranz, Cid and Muro (2000), Galiani and Hopenhayn (2003) and Cerimedo (2004).
} 
this possibility is likely to inflate the (negative) effect of Plan Jefes on transition to employment. To deal with this key concern we use three different approaches.

First, we estimate equations (1) - (4) separately for males and females. As shown by Galasso and Ravallion (2004), as compared to applicants, Plan Jefes reduced the labor force inactivity of women by 21-27 percentage points but did not have any effect on the labor force inactivity of men. Accordingly, for men, the effect of Plan Jefes on the probability of transiting to employment is unaffected by inactivity concerns and the effect of the Plan on men's transition probability may be thought of as the appropriate magnitude of the Plan's impact.

Second, although there is no information on whether Plan Jefes participants were unemployed or in reality inactive before joining the program it is possible to combine information from the May 2002 and October 2002 surveys and draw a distinction between these two states at least for the 12 month panel. The October 2002 round allows us to identify, (previously unemployed or inactive) individuals who are on the Plan and who started receiving benefits in May. The May 2002 survey asks all unemployed individuals to provide information on the characteristics of the job they held prior to becoming unemployed. This information is not available for those who were inactive in May 2002 and comparing the number of people who provide this information with those on the Plan allows us to identify individuals who were certainly unemployed before joining the program. Thus, we also present estimates of equation (1) and (2) for the 12 
month panel after removing individuals for whom we do not have information on the job held prior to becoming unemployed. ${ }^{27}$

As a final step to account for inactivity, we go beyond a two-state model and explicitly estimate the probability of Plan Jefes on transiting to employment and to inactivity. To do so, we estimate the specifications outlined in equation (1) and (2) using a three-state multinomial logit model. ${ }^{28}$

\section{Descriptive Statistics}

Table 3 and Table A2 contain descriptive statistics for the longer and shorter panel, respectively. The information is presented for the samples as a whole and conditional on Plan participation or applicant status. As shown in Table 3, for the sample as a whole, about 40 percent of the unemployed are household heads and 60 percent are male. The average age of an unemployed individual is 34 years and about 18 percent have had some form of tertiary education. A comparison of the means across Plan status shows that except for a few of the observed characteristics there are sharp differences between Plan and non-Plan individuals. While 35 percent of non-Plan individuals are household heads, the figure for Plan participants is 47 percent. This is surprising, as in principle, only unemployed household heads are eligible for the program. However, as is

\footnotetext{
${ }^{27}$ A concern with this exclusion is that individuals who are unemployed and have never held a job are also excluded. However, it is likely that the bulk of the excluded are those who were inactive prior to joining the program. Of the 266 Plan Jefes individuals who are employed or unemployed in May 2003, 136 do not provide information on the job held prior to joining the Plan and are removed from some of the specifications. Of these, 101 are women, underlining the finding that the effect of the Plan on reducing inactivity mainly affects women.

${ }^{28}$ Implicit in the two-state and three-state models is the validity of the independence of irrelevant alternatives (IIA) that underlies the use of a multinomial logit specification. If IIA holds then inactivity should be an irrelevant option and there should be no systematic difference in the coefficients obtained from a two-state or a three-state model. Of course it is possible that the effect of Plan Jefes differs across the two-state and three-state model while at the same time supporting the IIA assumption.
} 
clear, the condition that Plan Jefes participants must be household heads was not closely followed by program administrators.

A majority (65 percent) of non-Plan individuals are male, in contrast, Plan participation is dominated by women (66 percent). There are sharp differences in educational attainment. About 22 percent of the non-Plan individuals have some tertiary education while the corresponding figure for Plan participants is 8.7 percent. Consistent with the group targeted by the UA program, Plan participants tend to have larger household sizes and more children below the age of 14 . Despite the educational differences, it is notable that at least for the smaller subset of individuals on whom there is information on the quality of the job they held prior to becoming unemployed, differences across groups are not pronounced. Both Plan and non-Plan participants have a high incidence of prior job experience (92 versus 85 percent). A similar proportion were wage employees (as opposed to being self-employed) and a similar proportion held temporary or ad-hoc jobs. Nevertheless, the overall impression emerging from a comparison of the means is that Plan participants and non-Plan individuals have very different observed characteristics.

In contrast, a comparison of Plan participants and Plan applicants shows that except for gender and the number of children below age 14 the two groups have very similar observed characteristics. The proportion of household heads, marital status, quality of job prior to becoming unemployed, educational and regional distribution across the two groups is not statistically different. Thus, while comparisons between Plan and non-Plan participants may not be particularly apt, at least on the basis of the similarities 
in the observed characteristics of Plan participants and applicants, it does seem that Plan applicants are an appropriate control group for Plan participants.

The descriptive statistics for the 6 month panel reveals a similar picture. While the observed characteristics of Plan participants and non-Plan individuals differ sharply, except for a few variables, the observed characteristics of Plan participants and Plan applicants are not statistically different.

\section{Effect of Plan Jefes on Transition to Employment}

\section{V.1 Labor market transitions}

Table 4 relies on the one-year panel and displays labor market transitions for the various categories between May 2002 and May 2003 while Table 5 provides information on the transitions observed in the 6 month panel. Overall, by May 2003, of the 1,455 unemployed individuals in May 2002, about 38 percent find employment, a similar percentage remains unemployed while 23 percent drop out of the labor market. There are sharp differences in the distribution of labor market status conditional on receiving unemployment assistance. By May 2003, 44 percent of those without benefits have found work, while the corresponding figure for those receiving unemployment assistance is 19 percent. As shown in Table 4, due to differences in the characteristics of individuals on the Plan as compared to those without, comparisons may not be appropriate. A better comparison group may be individuals who have applied for UA benefits. However, even as compared with this group, Plan participants are substantially less likely to transit to employment. In fact, the group of applicants has a transition probability which is quite similar to those who do not receive any benefits (41 percent of applicants transit to employment). 
The figures for the 6 month panel follow a similar pattern. By May 2003, 31 percent of the 3,161 individuals unemployed in October 2002 transit to employment. The transition rate for those without benefits (38.4 percent) and those on unemployment insurance is quite similar (39.1 percent). Applicants have a slightly lower transition rate of 33 percent, but with a 15 percent transition rate, Plan Jefes beneficiaries are far less likely to transit to employment.

While the patterns of transition are similar for both panels, the additional information provided by the 12 month panel is the interesting temporal pattern of transition. For unemployed individuals as a whole, the bulk of the transition occurs between May 2002 and October 2002. 28 percent of the unemployed transit to employment in the first time period while a further 10 percent of the original sample transits between October 2002 and May 2003. This pattern holds for the group not receiving any benefits as well as for applicants. As shown in Table 4, 36 percent of those without benefits move to employment in 6 months while another 8 percent transits in the following 6 months. A similar story holds for those who do not receive benefits but have applied for UA. The transition rates are 35 percent and 6 percent in the first and second period, respectively. The transition pattern for those who receive benefits is the opposite. In the first 6 months only about 4 percent of those who were unemployed and on the Plan move to employment. In the next 6 months the probability of transitioning triples from 4 percent to 14.6 percent. The increase in the transition rate is consistent with the idea that 
over time, due to the erosion of the real value of the benefits the cost of remaining unemployed increases thereby promoting transition to employment. ${ }^{29}$

\section{V.2 Logit Estimates}

Table 6 provides estimates of equation (1) and (2). Non-participants are the comparison group in columns 1 and 2, while Plan applicants serve as the comparison group in columns 3 and 4. Column (2) and (4) are estimated over a smaller set of individuals on whom we have information on characteristics of the job they held prior to becoming unemployed. As explained in the previous section, these estimates should not be influenced by inactivity as they are restricted to those individuals who were certainly unemployed before joining Plan Jefes.

Regardless of the column that we consider, participation in Plan Jefes is clearly associated with a reduction in the probability of transiting to employment. As compared to non-participants, Plan Jefes participants are 33 to 36 percentage point less likely to transit to employment. The appropriate comparison in terms of identifying the causal effect of the Plan is to compare Plan participants with applicants and even versus this group the negative effect of Plan Jefes is quite large and ranges from 21.6 (column 2) to 32.4 (column 4) percentage points. The inclusion of the labor market characteristics does not alter the negative effect of the Plan. Unemployment insurance also exerts a negative effect but it is quite small and statistically insignificant.

\footnotetext{
29 The temporal patterns are also consistent with the idea that Plan recipients can afford to search for a better job match. Indeed, in terms of job quality, the mean (std. dev.) monthly wage for 143 Plan participants who are employed by May 2003 is Pesos 226 (168) a month while for the 60 applicants it is Pesos 206 (145) per month. Although, average wages are higher for former Plan participants, the difference in mean wages is not statistically significant.
} 
Other than the effect of the Plan, the estimates in Table 6 show that males and household heads are far more likely to exit to employment. The effects in column (3) and (4) display that males are 19 to 23 percentage points more likely to exit to employment as compared to females while the effect for household heads ranges from 11 to 18 percent. Age has a non-linear impact. None of the other variables in columns (3) or (4) exert an impact on transiting to employment. Given the strong similarities between Plan participants and applicants this is not particularly surprising.

Table 7 and 8 present gender-specific estimates of equation (1) and (2) based on the 12 month and the 6 month panel, respectively. As Table 7 shows, the marginal effect of Plan Jefes is much smaller for males. As compared to applicants, for male Plan Jefes participants, the negative effect of the program lies between 13.5 (column 1) and 22.9 (column 3) percentage points while for females the effect is about 40 percentage points. Based on the shorter panel, the negative effect for males lies between 18.6 (column 5) and 22.6 (column 2) while for females the effect is about 31 percentage points. As mentioned earlier, Plan Jefes attracted women who were inactive into the labor market, and treating these women as unemployed is likely to exaggerate the negative effect of the Plan. The substantially larger estimates for women support this idea. Given that the Plan has no effect on inactivity rates for men, it may be appropriate to view the results based on the male sample as a lower bound of the negative effect of the Plan on transiting to employment.

\section{V.3 Propensity Score Matching Estimates}

Logit specifications were used to estimate the propensity of participating in Plan

Jefes. The specifications included the individual $(I)$, household $(H H)$ and regional 
controls discussed above. For the one-year panel, for both sets of control groups, postmatching tests supported the null hypothesis of equality of means of each variable between the treatment and the control groups. ${ }^{30}$ The similarities between the Plan Jefes participants and the applicant group are reflected in the large regions of common support displayed in Figures 1 and 2.31

Table 9 presents ATT estimates of the program on the probability of transiting to employment. Following (3) and (4) these estimates are based on matching Plan participants to non-participants (excluding those on UI and applicants) and on matching Plan participants only to the pool of applicants. Estimates are presented for the longer and shorter panel as well as separately for males and females. According to the PSM estimates, Plan participants are about 32 to 38 percentage points less likely to transit to employment, which is somewhat larger than the estimates based on the logit model. The effect differs across gender and lies between 17 to 26 percentage points for men and is about 40 percentage points for women. Notwithstanding the larger effect for the total sample, the overall flavor that emerges from Table 9 is that PSM estimates are not substantially different from the logit estimates.

\section{V.4 Multinomial Logit Estimates}

Multinomial logit estimates of the effect of Plan Jefes on transiting to employment and inactivity are displayed in Tables 10-12. The MNL estimates of Plan

\footnotetext{
${ }^{30}$ In the interests of brevity the logit estimates and the tests for equality of means are not presented in the paper. Briefly, the logit estimates showed that more educated individuals are less likely to join the program while being female, a household head, and having a larger family are positively associated with participation. The post-matching equality of means across the treatment and control group suggests that on average the treated and control groups are observationally identical.

${ }^{31}$ In the 12 month panel, 5 (1.8 percent) of the participants are off the common support while the corresponding figure for the 6 month panel is 37 (4.6 percent).
} 
Jefes, based on Plan participants and non-applicants (Table 10, column 5), are about 5 percentage points smaller than the effects based on the logit model (Table 6, column 3). Apart from this change, the differences between the logit and the MNL estimates are not pronounced, supporting the idea that unemployment and inactivity are two distinct states. $^{32}$ Gender-specific estimates for the longer and shorter panel are presented in Tables 11 and 12, respectively. ${ }^{33}$ These estimates display that participation in Plan Jefes reduces the probability of transiting to employment by 12 (Table 11, column 2) to 19 (Table 12, column 2) percentage points for males and 16 (Table 12, column 5) to 19 (Table 11, column 5) percentage points for females. The estimates confirm the effect of the Plan on reducing inactivity and highlight the importance of controlling for this, especially for women. While the Plan has no influence on the labor force activity of men it tends to reduce inactivity for women by 25 to 27 percentage points. Overall, based on the MNL estimates the effect of the Plan on males is in the same range as reported earlier, while for females the estimates are smaller and are now in about the same range as that for men.

\section{Discussion and concluding remarks}

This paper examined the effect of Plan Jefes, an unemployment assistance program on the probability of transiting to employment between the period May 2002 and May 2003. Regardless of the data set, the specification, the empirical approach and the

\footnotetext{
32 Test statistics based on a comparison of the multinomial logit and logit estimates for the sample of Plan participants and non-participants yielded a p-value of 0.682 , while a comparison of the multinomial logit and logit estimates for Plan participants and applicants yielded a p-value of 0.874 . Thus, the null hypothesis of IIA is not rejected and in principle, the logit estimates of Plan Jefes are not influenced by the addition of inactivity as a possible outcome.

${ }^{33}$ The gender specific estimates are provided only for the full sample. Due to the small sample size, it was not possible to estimate gender-specific three-state models for the sample of Plan participants and applicants.
} 
control group, the evidence assembled in this paper shows that individuals enrolled in the Plan are less likely to transit to employment as compared to individuals who are not on the Plan. For males, the lower bound of the effect of Plan Jefes is about 12 percentage points (Table 11, column 2) while for females it is about 16 percentage points (Table 12, column 5). Since the negative effect of the program tends to be larger for females, over time, the composition of program participants and indeed of the unemployed becomes increasingly feminized. The results presented in the paper also showed that Plan participants who do exit to employment tend to delay their exit. Most of their exits were in the period October 2002 to May 2003. For non-participants and applicants the pattern was the opposite and exits were concentrated in the period May 2002 to October 2002. These results may be interpreted in the context of job-search models which suggest that by reducing the costs of being unemployed, programs like Plan Jefes raise reservation wages and reduce search intensity, thereby reducing the probability of transiting to employment.

While the results are consistent with the supply-side effects predicted by jobsearch models, it is possible that there are demand-side factors that are responsible for the lower exit rate of Plan participants to employment. For example, Plan participants may be seeking jobs with the same intensity as non-participants/applicants but due to statistical discrimination/stigmatization they are unable to graduate from the program. Some evidence on this possibility is available. In 2002, the Argentinean Ministry of Labor conducted a survey among 1,290 firms which enquired whether employers would 
be willing to hire Plan participants if they met the qualifications required for a job. ${ }^{34} 78$ percent of the firms responded positively. Employers who were unwilling to hire Plan Jefes participants cited lack of skills, experience, references and trust. In the case of 10 percent of the firms lack of trust or stigmatization was the main reason for not hiring Plan Jefes participants. While we can't quantify the effect of the reluctance to hire Plan Jefes participants on our estimates, given the empirical evidence assembled in the paper it is hard to dismiss the supply-side effects and the idea that the unlimited duration of Plan benefits provides strong incentives to remain unemployed.

At its inception about 60 percent of the Plan participants were women and about 47 percent were household heads. Currently about 72 percent of the beneficiaries are females and in 2003 only about 41 percent were household heads. Clearly, the objective of providing a short-term safety net for unemployed heads of households is only partially met. At the moment, individuals who are genuinely unemployed and cannot access UI are unlikely to receive support. On the other hand the program appears to have been successful in drawing women into the labor market. Notwithstanding the protection that the Plan provided for some households during the economic crisis and its role in promoting women's labor force participation, it does appear that Plan participants are less likely to transit to employment and may have become dependent on the Plan.

At the moment, various plans to relocate the approximately 1 million Jefes participants are under consideration. These include the relocation of participants to either a social safety program which does not focus on employment or a program that provides

\footnotetext{
${ }^{34}$ The survey was conducted in 2002 and included firms located in the four largest urban areas of Argentina. Further details are available in Franceschelli (2005) and Encuesta de Indicadores Laborales at www.trabajo.gov.ar.
} 
training and limited duration support to the genuinely unemployed. The results presented in this paper suggest that the Plan does indeed need to be re-visited in accordance with the objectives for which it was created. Reorganizing and restructuring the Plan so that it meets its stated goal of providing unemployment benefits and training for the short-term unemployed while at the same time providing an alternative social program for the longer-term unemployed and the inactive may be an appropriate approach. 


\section{References}

Adamchick, V., 1999. The effects of unemployment benefits on the probability of reemployment in Poland. Oxford Bulletin of Economics and Statistics, 61, 95-108.

Angrist, J.D., 1998. Estimating the labor market impacts of voluntary military service using social security data on military applicants. Econometrica 66, 249-88.

Arranz, J.M., Cid, J.C. and Muro, J., 2000. La duración del desempleo en presencia de altas tasas de paro: el caso de la Argentina. Unpublished manuscript.

Atkinson, A. and Micklewright, J., 1991. Unemployment compensation and labor market transitions: A critical review. Journal of Economic Literature, 29, 1679-1727.

Bertranou, F. and Bonari, D., 2005. Protección Social en Argentina. Financiamiento, cobertura y desempeño. International Labour Organization.

Blanchard, O.J., Diamond, P., 1994. Ranking, unemployment duration and wages. Review of Economic Studies 61, 417-434.

Calmfors, L. and Holmlund, B., 2000. Unemployment and Economic Growth: A partial survey. Swedish Economic Policy Review 7, 107-153.

Campos, L., 2000. Trabajar sin derechos'. Paper presented at Centro de Estudios Legales y Sociales.

Card D. and Levine, P.B., 2000. Extended benefits and the duration of UI spells: evidence from the New Jersey extended benefit program, Journal of Public Economics 78, 107-38.

Carling, K., Holmlund B. and Vejsiu, A., 2001. Do benefit cuts boost job finding Swedish evidence from the 1990s. Economic Journal 111, 766-90.

Cerimedo, F., 2004. Duración del desempleo y ciclo económico en la Argentina. Universidad Nacional de La Plata. Working Paper No. 53.

Chase,R.S.,2002. Supporting communities in transition: The impact of the Armenian social investment fund. The World Bank Economic Review 16, 219-40.

Cruces, G. and Wodon Q., 2002. Risk-adjusted poverty in Argentina: Measurement and determinants. Mimeo. London School of Economics, London, U.K.

Decree Number 565/02. Available at http://infoleg.mecon.gov.ar.

Duncan, A., 2002, Respuestas del empleo a cambios en la política fiscal obtenidas mediante microsimulación. Conference Paper, Institute of Fiscal Studies, Madrid

Employment Law, 1991. Available at http://infoleg.mecon.gov.ar.

Franceschelli, I., 2005. Poverty and employability effects of workfare programs in Argentina. Mimeo. Poverty Monitoring, Measurement and Analysis Network.

Galasso, E. and Ravallion, M., 2004. Social protection in a crisis: Argentina's Plan Jefas y Jefes. The World Bank Economic Review, 18, 367-399.

Galiani, S. and Hopenhayn, H., 2001. Duration and Risk of Unemployment in Argentina. Conference paper. CIDER, University of California, Berkeley.

Holmlund, B., 1998. Unemployment insurance in theory and practice. Scandinavian Journal of Economics 100, 113-141.

INEI, 2000. Dinámica del desempleo. Paper presented by Instituto Nacional de Estadística e Informática. Lima, Perú.

INDEC, 2001. Encuesta Permanente de Hogares: Base Usuaria Ampliada, available at http://www.indec.mecon.gov.ar/eph/. 
INDEC, 2002. Mercado de Trabajo. Principales indicadores de aglomerados urbanos. Información de Prensa.

INDEC, 2002. Instructivo para contabilizar los beneficiares del Plan Jefes.

INDEC, 'Permanent Household Survey' Rounds October 2002 and May 2003.

Jenkins S.P. and C. Garcia-Serrano, 2004, The Relationship between Unemployment Benefits and Re-employment probabilities: Evidence from Spain, Oxford Bulletin of Economics and Statistics, 66, 239-260.

Katz, L. and Meyer, B.D.,1990. The impact of the potential duration of unemployment benefits on the duration of unemployment. Journal of Public Economics 41, 4572.

Lanari, M., 2003. Las políticas de empleo en los países del MERCOSUR, 1990 - 2003. Estudio analítico sobre programas de empleo ejecutados en Argentina'. Paper prepared for the Observatorio del Mercado de Trabajo del MERCOSUR.

Lubyova M. and van Ours J, 1998. Work incentives and other effects of the transition to social assistance: Evidence from the Slovak Republic, Empirical Economics, 23 121-153.

Mazza, J., 2000. Unemployment insurance: Case studies and lessons for Latin America and Caribbean. Inter-american Development Bank. Working Paper No. 411.

MECON, 2003. Efectos de los Planes Jefes y Jefas sobre el empleo: Notas de Coyuntura. Paper prepared by Dirección Nacional de Coordinación de Políticas Macroeconómicas.

McKenzie, D., 2004. Aggregate shocks and labor market responses: Evidence from Argentina's financial crisis. Economic Development and Cultural Change 52,719-758.

Meyer, B.D., 1990. Unemployment Insurance and Unemployment Spells. Econometrica $58,757-782$.

Meyer, B., 2002. Unemployment and workers' compensation programmes: Rationale, design, labour supply and income support. Fiscal Studies, 23, 1-49.

Micklewright, J. and Gyula, N., 1998. Unemployment assistance in Hungary. Empirical Economics 23, 155-175.

Módolo, C., 2004. Los peligros institucionales del Plan Jefas y Jefes de Hogar’ Paper presented at the Novenas Jornadas "Investigaciones en la Facultad" de Ciencias Económicas y Estadística.

Moffitt, R. and Nicholson, W.,1982. The effect of unemployment insurance on unemployment: The case of supplemental benefits. Review of Economics and Statistics 64, 1-11.

Monza, A., 2002. Los dilemas de la política de empleo en la coyuntura argentina actual. Fundación OSDE - CIEPP.

Mortensen, D., 1977. Unemployment insurance and job search decisions, Industrial and Labor Relations Review 30, 505-17.

Mortensen, D.T., 1986. Job search and labor market analysis. In Ashenfelter O. and Layard R., (Eds.), Handbook of Labor Economics, vol. 2. North-Holland, Amsterdam, pp.849-897.

MTESS, 2004. Segunda evaluación del Programa Jefes de Hogar. Resultados de la encuesta a beneficiarios. Subsecretaría de Programación Técnica y Estudios Laborales. 
MTESS, 2002. Impacto macroeconómico del Programa Jefas y Jefes de Hogar. Paper presented by Dirección General de Estudios y Formulación de Política de Empleo.

Ortega Masagué, A., 2006. El diferencial entre las tasas de desempleo de hombres y mujeres en Argentina. Paper presented in Fedea, DT 2006-08.

Pissarides, C.A., 1992. Loss of skill during unemployment and the persistence of economic shocks. Quarterly Journal of Economics 107, 1371-1391.

Roca, E., Capelletti, B., Langieri, M., Muscolino, M., Soto, C., 2003. Plan Jefas y Jefes de Hogar Desocupados: política de empleo o política social? Paper presented at the meetings of the Asociación Argentina de Especialistas en Estudios del Trabajo. Buenos Aires.

Roed K. and T. Zhang, 2005, Unemployment duration and economic incentives: A quasirandom assignment approach. European Economic Review 49, 1799-1825.

Rosenbaum, P.R. and Rubin, D.B., 1983. The central role of the propensity score in observational studies for causal effects. Biometrika 70, 41-55.

Samaniego, N., 2002. Las políticas de mercado de trabajo y su evaluación en América Latina. CEPAL/ECLAC, Serie 19, Santiago de Chile.

Tcherneva, P. and Wray, L., 2005. Employer of last resort program: A case study of Argentina's Jefes de Hogar Program. Working Paper No. 41. Centre for Full Employment and Price Stability, University of Missouri-Kansas City.

Tzannatos, Z. and Roddis, S., 1998. Unemployment Benefits. Social Protection Discussion Papers No. 9813. The World Bank.

van den Berg, G. and van Ours J., 1997. Eyeballing state dependence and unobserved heterogeneity in aggregate unemployment duration Data. Research in Labor Economics 16, 369-394.

Vella, F., 1993. A simple estimator for simultaneous models with censored endogenous regressors. International Economic Review 34, 441-457.

Vodopivec, M. 2004. 'Comparing Unemployment Insurance and Unemployment Assistance'. Employment Policy Primer. The World Bank. 
Table 1

Labor market indicators, selected years ${ }^{\text {a }}$

\begin{tabular}{|c|c|c|c|c|c|c|}
\hline & \multicolumn{6}{|c|}{ Year } \\
\hline Population, in thousands & 1991 & 1993 & 2000 & 2001 & 2002 & 2003 \\
\hline Total Population - TP & 28,447 & 29,426 & 32,842 & 33,484 & 34,124 & 34,393 \\
\hline Inactive population & 17,408 & 17,671 & 19,197 & 19,575 & 19,989 & 20,000 \\
\hline Active population $-\mathrm{A}$ & 11,039 & 11,755 & 13,644 & 13,909 & 14,135 & 14,393 \\
\hline Unemployed - U & 748 & 1,096 & 2,031 & 2,375 & 2,737 & 2,202 \\
\hline Employed - E & 10,291 & 10,660 & 11,613 & 11,534 & 11,397 & 12,191 \\
\hline Underemployed $-\mathrm{S}^{\mathrm{b}}$ & 963 & 1,092 & 1,972 & 2,178 & 2,696 & 2,647 \\
\hline \multicolumn{7}{|l|}{ Rates, in percentage ${ }^{\mathrm{c}}$} \\
\hline Activity rate $-\mathrm{AR}$ & 39.5 & 41.3 & 42.6 & 42.5 & 42.4 & 42.8 \\
\hline Employment rate - ER & 37.0 & 37.3 & 36.2 & 35.2 & 34.1 & 36.2 \\
\hline Unemployment rate - UR & 6.5 & 9.6 & 15.1 & 17.4 & 19.7 & 15.6 \\
\hline Underemployment rate - SR & 9.4 & 10.2 & 17.0 & 18.9 & 23.7 & 21.7 \\
\hline Informal workers ${ }^{\mathrm{d}}$ & 29.7 & 31.3 & 37.7 & 38.3 & 40.9 & 44.8 \\
\hline
\end{tabular}

Notes: ${ }^{a}$ Year averages, except for 2003 which is based on data collected in May of that year. ${ }^{b}$ Employed individuals working less than 35 hours per week who want to work longer hours. ${ }^{c}$ Rates calculated on the basis of standard definitions: $\mathrm{AR}=\mathrm{A} / \mathrm{TP}, \mathrm{ER}=\mathrm{E} / \mathrm{TP}, \mathrm{UR}=\mathrm{U} / \mathrm{A}, \mathrm{SR}=$ S/E. ${ }^{\mathrm{d}}$ Percentage of salaried workers that work outside the regulated labor market. Source: Statistics are from Ministry of Labor, Employment and Social Security (MTESS) and are based on survey data.

Table 2

Recipients of Unemployment Insurance and Unemployment A
\begin{tabular}{|l|c|c|}
\hline Year & $\begin{array}{c}\text { Unemployment } \\
\text { Insurance } \\
\text { (Recipients) }\end{array}$ & $\begin{array}{c}\text { Unemployment } \\
\text { Assistance } \\
\text { (Recipients) }\end{array}$ \\
\hline 1996 & 128,672 & $\cdot$ \\
1997 & 95,379 & $\cdot$ \\
1998 & 90,711 & $\cdot$ \\
1999 & 114,716 & $\cdot$ \\
2000 & 124,535 & $\cdot$ \\
2001 & 144,738 &. \\
2002 & 200,398 & $1,126,387$ \\
2003 & 105,371 & $2,128,408$ \\
2004 & 62,407 & $1,919,919$ \\
2005 & 61,674 & $1,747,455$ \\
2006 & 80,689 & $1,527,691$ \\
\hline
\end{tabular}

Source: Based on Betranou and Bonari (20005) and administrative data from the Ministry of Labor, Employment and Social Security (MTESS). 


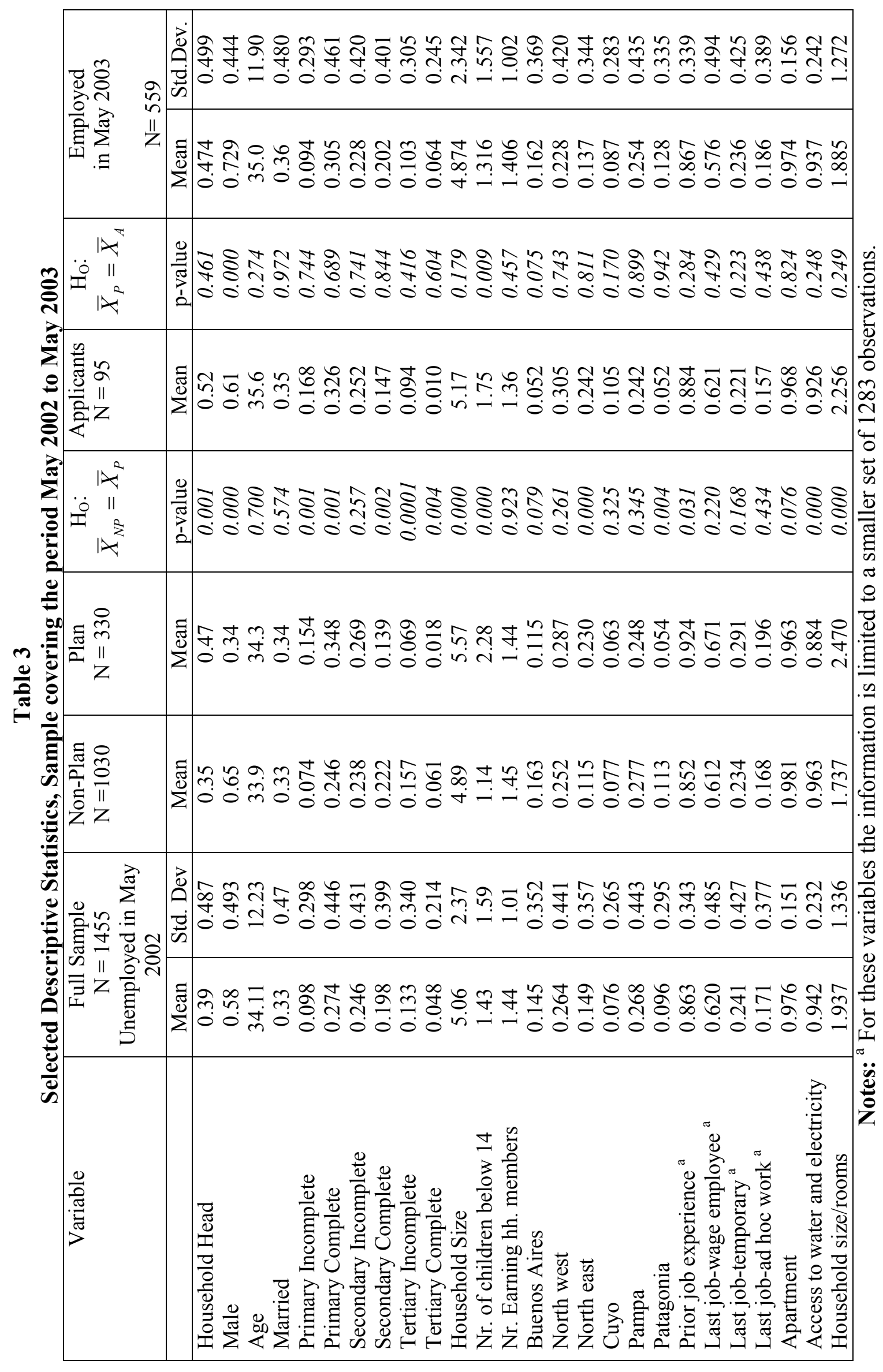


Table 4

Transitions in Labor Market Status between May 2002 and May 2003 (percent)

\begin{tabular}{|c|c|c|c|}
\hline \multicolumn{4}{|c|}{ Full Sample } \\
\hline $\begin{array}{l}\text { Unemployed in } \\
\text { May 2002, } N=1,455\end{array}$ & $\begin{array}{c}\text { Situation in } \\
\text { October } 2002\end{array}$ & $\begin{array}{c}\text { Between } \\
\text { October } 2002 \\
\text { and May } \\
2003\end{array}$ & $\begin{array}{l}\text { Situation in } \\
\text { May } 2003\end{array}$ \\
\hline $\begin{array}{l}\text { To Employment } \\
\text { To Unemployment } \\
\text { To inactivity }\end{array}$ & $\begin{array}{c}413 \\
(28.4) \\
718 \\
(49.3) \\
323 \\
(22.2) \\
\end{array}$ & $\begin{array}{c}+146 \\
(10) \\
-159 \\
(10.9) \\
+13 \\
(0.8)\end{array}$ & $\begin{array}{c}559 \\
(38.4) \\
559 \\
(38.4) \\
336 \\
(23) \\
\end{array}$ \\
\hline \multicolumn{4}{|c|}{ Without benefits and non-applicants } \\
\hline $\begin{array}{l}\text { Unemployed in } \\
\text { May 2002, } N=1,003\end{array}$ & $\begin{array}{c}\text { Situation in } \\
\text { October } 2002\end{array}$ & $\begin{array}{c}\text { Between } \\
\text { October } 2002 \\
\text { and May } \\
2003\end{array}$ & $\begin{array}{l}\text { Situation in } \\
\text { May } 2003\end{array}$ \\
\hline $\begin{array}{l}\text { To Employment } \\
\text { To Unemployment } \\
\text { To inactivity }\end{array}$ & $\begin{array}{c}363 \\
(36.2) \\
383 \\
(38.2) \\
256 \\
(25.5)\end{array}$ & $\begin{array}{c}+82 \\
(8.2) \\
-78 \\
(7.8) \\
-4 \\
(0.4)\end{array}$ & $\begin{array}{c}445 \\
(44.3) \\
305 \\
(30.4) \\
252 \\
(25.1)\end{array}$ \\
\hline \multicolumn{4}{|c|}{ With UA } \\
\hline $\begin{array}{l}\text { Unemployed in } \\
\text { May } 2002, N=330\end{array}$ & $\begin{array}{c}\text { Situation in } \\
\text { October } 2002\end{array}$ & $\begin{array}{c}\text { Between } \\
\text { October } 2002 \\
\text { and May } \\
2003\end{array}$ & $\begin{array}{l}\text { Situation in } \\
\text { May } 2003\end{array}$ \\
\hline $\begin{array}{l}\text { To Employment } \\
\text { To Unemployment } \\
\text { To inactivity }\end{array}$ & $\begin{array}{c}14 \\
(4.2) \\
263 \\
(79.7) \\
53 \\
(16.1) \\
\end{array}$ & $\begin{array}{c}+48 \\
(14.6) \\
-59 \\
(17.9) \\
11 \\
(3.3) \\
\end{array}$ & $\begin{array}{c}62 \\
(18.8) \\
204 \\
(61.8) \\
64 \\
(19.4) \\
\end{array}$ \\
\hline \multicolumn{4}{|c|}{ Applicants } \\
\hline $\begin{array}{l}\text { Unemployed in } \\
\text { May 2002, } N=95\end{array}$ & $\begin{array}{c}\text { Situation in } \\
\text { October } 2002\end{array}$ & $\begin{array}{c}\text { Between } \\
\text { October } 2002 \\
\text { and May } \\
2003\end{array}$ & $\begin{array}{l}\text { Situation in } \\
\text { May } 2003\end{array}$ \\
\hline $\begin{array}{l}\text { To Employment } \\
\text { To Unemployment } \\
\text { To inactivity }\end{array}$ & $\begin{array}{c}33 \\
(34.7) \\
48 \\
(50.5) \\
14 \\
(14.7) \\
\end{array}$ & $\begin{array}{c}+6 \\
(6.3) \\
-8 \\
(8.4) \\
+2 \\
(2.1) \\
\end{array}$ & $\begin{array}{c}39 \\
(41) \\
40 \\
(42.1) \\
16 \\
(16.8) \\
\end{array}$ \\
\hline
\end{tabular}


Table 5

Transitions in Labor Market Status between October 2002 and May 2003 (percent)

\begin{tabular}{|c|c|c|c|c|c|}
\hline & All & $\begin{array}{c}\text { Without } \\
\text { benefits \& } \\
\text { non } \\
\text { Applicants }\end{array}$ & With UA & Applicants & With UI \\
\hline $\begin{array}{l}\text { Unemployed in } \\
\text { October } 2002\end{array}$ & 3,161 & 1,904 & 982 & 207 & 69 \\
\hline \multicolumn{6}{|c|}{ Labor market status in May 2003, absolute numbers (percent) } \\
\hline To Employment & $\begin{array}{c}974 \\
(30.8)\end{array}$ & $\begin{array}{c}732 \\
(38.4)\end{array}$ & $\begin{array}{r}147 \\
(15)\end{array}$ & $\begin{array}{c}68 \\
(32.9)\end{array}$ & $\begin{array}{c}27 \\
(39.1)\end{array}$ \\
\hline To Unemployment & $\begin{array}{l}1,444 \\
(45.7)\end{array}$ & $\begin{array}{l}645 \\
(33.9)\end{array}$ & $\begin{array}{c}692 \\
(70.5)\end{array}$ & $\begin{array}{c}77 \\
(372)\end{array}$ & $\begin{array}{c}31 \\
(449)\end{array}$ \\
\hline To Inactivity & $\begin{array}{l}742 \\
(23.5)\end{array}$ & $\begin{array}{l}526 \\
(27.6)\end{array}$ & $\begin{array}{c}143 \\
(14.6)\end{array}$ & $\begin{array}{c}62 \\
(30)\end{array}$ & $\begin{array}{c}11 \\
(15.9)\end{array}$ \\
\hline
\end{tabular}


Table 6

Logit Marginal Effects Estimates

Transition to Employment between May 2002 and May 2003

\begin{tabular}{|c|c|c|c|c|}
\hline Variable & $\begin{array}{c}\text { (1) } \\
\text { Full Sample }\end{array}$ & $\begin{array}{c}(2) \\
\text { Full Sample }\end{array}$ & $\begin{array}{c}\text { (3) } \\
\text { Restricted to } \\
\text { UA and } \\
\text { Applicants }\end{array}$ & $\begin{array}{c}\text { (4) } \\
\text { Restricted to } \\
\text { UA and } \\
\text { Applicants }\end{array}$ \\
\hline Unemployment Assistance & $\begin{array}{l}-0.357 * * * \\
(0.037)\end{array}$ & $\begin{array}{l}-0.334 * * * \\
(0.046)\end{array}$ & $\begin{array}{l}-0.261 * * * \\
(0.070)\end{array}$ & $\begin{array}{l}-0.324 * * * \\
(0.083)\end{array}$ \\
\hline Applicant & $\begin{array}{l}-0.108^{*} \\
(0.060)\end{array}$ & $\begin{array}{l}-0.118^{*} \\
(0.063)\end{array}$ & - & - \\
\hline Unemployment Insurance & $\begin{array}{c}-0.032 \\
(0.084)\end{array}$ & $\begin{array}{c}-0.042 \\
(0.087)\end{array}$ & 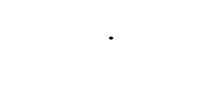 & . \\
\hline Household Head & $\begin{array}{l}0.095 * * \\
(0.046)\end{array}$ & $\begin{array}{c}0.081 * \\
(0.050)\end{array}$ & $\begin{array}{c}0.107^{*} \\
(0.074)\end{array}$ & $\begin{array}{c}0.181 * \\
(0.111)\end{array}$ \\
\hline Male & $\begin{array}{l}0.106^{* * *} \\
(0.039)\end{array}$ & $\begin{array}{c}0.071 * \\
(0.043)\end{array}$ & $\begin{array}{l}0.192^{* * *} \\
(0.068)\end{array}$ & $\begin{array}{l}0.228 * * * \\
(0.097)\end{array}$ \\
\hline Age & $\begin{array}{c}0.016^{*} \\
(0.009)\end{array}$ & $\begin{array}{c}0.012 \\
(0.010)\end{array}$ & $\begin{array}{l}0.045^{* *} \\
(0.018)\end{array}$ & $\begin{array}{l}0.046^{* *} \\
(0.026)\end{array}$ \\
\hline Age squared*100 & $\begin{array}{l}-0.024 * * \\
(0.012)\end{array}$ & $\begin{array}{l}-0.022 * \\
(0.013)\end{array}$ & $\begin{array}{l}-0.064^{*} \\
(0.025)\end{array}$ & $\begin{array}{l}-0.068 * * * \\
(0.034)\end{array}$ \\
\hline Married & $\begin{array}{c}-0.023 \\
(0.041)\end{array}$ & $\begin{array}{l}-0.017 \\
(0.043)\end{array}$ & $\begin{array}{l}-0.027 \\
(0.058)\end{array}$ & $\begin{array}{l}-0.011 \\
(0.088)\end{array}$ \\
\hline Primary Complete & $\begin{array}{c}0.055 \\
(0.059)\end{array}$ & $\begin{array}{c}0.029 \\
(0.063)\end{array}$ & $\begin{array}{c}0.044 \\
(0.080)\end{array}$ & $\begin{array}{l}-0.002 \\
(0.105)\end{array}$ \\
\hline Secondary Incomplete & $\begin{array}{l}-0.015 \\
(0.063)\end{array}$ & $\begin{array}{l}-0.037 \\
(0.067)\end{array}$ & $\begin{array}{c}-0.018 \\
(0.086)\end{array}$ & $\begin{array}{l}-0.058 \\
(0.112)\end{array}$ \\
\hline Secondary Complete & $\begin{array}{c}0.010 \\
(0.065)\end{array}$ & $\begin{array}{l}-0.004 \\
(0.07)\end{array}$ & $\begin{array}{c}0.052 \\
(0.105)\end{array}$ & $\begin{array}{c}0.127 \\
(0.162)\end{array}$ \\
\hline Tertiary Incomplete & $\begin{array}{l}-0.039 \\
(0.073)\end{array}$ & $\begin{array}{l}-0.083 \\
(0.077)\end{array}$ & $\begin{array}{c}-0.134 \\
(0.091)\end{array}$ & $\begin{array}{l}-0.216 \\
(0.099)\end{array}$ \\
\hline Tertiary Complete & $\begin{array}{c}0.131 \\
(0.088)\end{array}$ & $\begin{array}{c}0.105 \\
(0.090)\end{array}$ & $\begin{array}{c}0.239 \\
(0.294)\end{array}$ & $\begin{array}{c}0.498 \\
(0.262)\end{array}$ \\
\hline Household Size & $\begin{array}{l}-0.009 \\
(0.012)\end{array}$ & $\begin{array}{l}-0.015 \\
(0.013)\end{array}$ & $\begin{array}{c}0.022 \\
(0.018)\end{array}$ & $\begin{array}{c}0.033 \\
(0.027)\end{array}$ \\
\hline Number of children below 14 & $\begin{array}{r}-0.0013 \\
(0.018)\end{array}$ & $\begin{array}{l}-0.000 \\
(0.019)\end{array}$ & $\begin{array}{l}-0.022 \\
(0.027)\end{array}$ & $\begin{array}{c}-0.044 \\
(0.039)\end{array}$ \\
\hline Number of earning household members & $\begin{array}{c}0.016 \\
(0.018)\end{array}$ & $\begin{array}{c}0.018 \\
(0.018)\end{array}$ & $\begin{array}{c}0.012 \\
(0.031)\end{array}$ & $\begin{array}{c}0.011 \\
(0.046)\end{array}$ \\
\hline Prior job experience & & $\begin{array}{l}0.202 * * \\
(0.088)\end{array}$ & 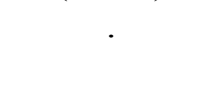 & $\begin{array}{l}-0.308 \\
(0.273)\end{array}$ \\
\hline Last job-wage employee & . & $\begin{array}{l}-0.109 * * \\
(0.050)\end{array}$ & . & $\begin{array}{c}0.127 \\
(0.109)\end{array}$ \\
\hline Last job-temporary & . & $\begin{array}{l}-0.024 \\
(0.045)\end{array}$ & . & $\begin{array}{l}-0.135 \\
(0.091)\end{array}$ \\
\hline Last job-ad hoc work & . & $\begin{array}{c}-0.052 \\
(0.056)\end{array}$ & . & $\begin{array}{l}-0.055 \\
(0.110)\end{array}$ \\
\hline $\begin{array}{l}N \\
\text { Log likelihood } \\
\text { Pseudo } R^{2}\end{array}$ & $\begin{array}{c}1118 \\
-697.34 \\
0.10\end{array}$ & $\begin{array}{c}982 \\
-627.14 \\
0.074\end{array}$ & $\begin{array}{c}345 \\
-175.90 \\
0.156\end{array}$ & $\begin{array}{c}209 \\
-105.43 \\
0.223\end{array}$ \\
\hline
\end{tabular}

Notes: Other regressors include a set of 5 regional indicators, controls for household wealth-type of housing, access to electricity and water, household members per room and indicators for size of firm of last job (only columns 2 and 4 ). ${ }^{*}, * *, * * *$ indicate significance at the 10 per cent, 5 per cent, and 1 per cent levels, respectively. 
Table 7

Gender Specific Logit Marginal Effects Estimates

Transition to Employment between May 2002 and May 2003

\begin{tabular}{|l|c|c|c|c|}
\multicolumn{2}{|c|}{ (Standard Errors) } \\
& $\begin{array}{c}(1) \\
\text { Full Sample } \\
\text { Male }\end{array}$ & $\begin{array}{c}(2) \\
\text { Full Sample } \\
\text { Female }\end{array}$ & $\begin{array}{c}(3) \\
\text { UA and } \\
\text { Applicants } \\
\text { Male }\end{array}$ & $\begin{array}{c}\text { UA and } \\
\text { Applicants } \\
\text { Female }\end{array}$ \\
\hline Unemployment Assistance & $-0.278^{* * *}$ & $-0.407^{* * *}$ & $-0.229^{*}$ & $-0.396^{* * *}$ \\
& $(0.066)$ & $(0.054)$ & $(0.125)$ & $(0.151)$ \\
Applicant & $-0.143^{*}$ & -0.047 & $\cdot$ & $\cdot$ \\
& $(0.080)$ & $(0.091)$ & &. \\
Unemployment Insurance & -0.007 & -0.137 & $\cdot$ & \\
& $(0.095)$ & $(0.117)$ & & 197 \\
Log likelihood & 674 & 409 & 112 & -68.99 \\
Pseudo R & -429.86 & -219.27 & -61.09 & 0.251 \\
\hline
\end{tabular}

Notes: Other regressors include head of household, age and age squared, indicators for educational level, married, household size, number of children below 14, number of earning household members, a set of 5 regional indicators, controls for household wealth and characteristics of previous job (only for males). ${ }^{*}, * *, * *$ indicate significance at the 10 per cent, 5 per cent, and 1 per cent levels, respectively.

Table 8

Logit Marginal Effects Estimates

Transition to Employment between October 2002 and May 2003

(Standard Errors)

\begin{tabular}{|c|c|c|c|c|c|c|}
\hline Variable & $\begin{array}{c}\text { (1) } \\
\text { Full Sample } \\
\text { Total }\end{array}$ & $\begin{array}{c}(2) \\
\text { Full Sample } \\
\text { Male }\end{array}$ & $\begin{array}{l}\text { (3) } \\
\text { Full Sample } \\
\text { Female }\end{array}$ & $\begin{array}{c}(4) \\
\text { UA and } \\
\text { Applicants } \\
\text { Total }\end{array}$ & $\begin{array}{c}(5) \\
\text { UA and } \\
\text { Applicants } \\
\text { Male }\end{array}$ & $\begin{array}{c}(6) \\
\text { UA and } \\
\text { Applicants } \\
\text { Female }\end{array}$ \\
\hline Unemployment Assistance & $\begin{array}{l}-0.339 * * * \\
(0.022)\end{array}$ & $\begin{array}{l}-0.295^{* * *} \\
(0.035)\end{array}$ & $\begin{array}{l}-0.333 * * * \\
(0.033)\end{array}$ & $\begin{array}{l}-0.243 * * * \\
(0.048)\end{array}$ & $\begin{array}{l}-0.186^{* * *} \\
(0.068)\end{array}$ & $\begin{array}{l}-0.313^{* * * *} \\
(0.109)\end{array}$ \\
\hline Applicant & $\begin{array}{l}-0.047 \\
(0.040)\end{array}$ & $\begin{array}{l}-0.069 \\
(0.058)\end{array}$ & $\begin{array}{l}-0.015 \\
(0.087)\end{array}$ & . & . & . \\
\hline Unemployment Insurance & $\begin{array}{c}-0.126 * * \\
(0.053)\end{array}$ & $\begin{array}{l}-0.147^{*} \\
(0.077)\end{array}$ & $\begin{array}{c}-0.077 \\
(0.071) \\
\end{array}$ & . & . & . \\
\hline $\begin{array}{l} \\
\text { Log likelihood } \\
\text { Pseudo } R^{2}\end{array}$ & $\begin{array}{c}2418 \\
-1433.02 \\
0.121\end{array}$ & $\begin{array}{c}1303 \\
-858.93 \\
0.05\end{array}$ & $\begin{array}{c}1115 \\
-557.33 \\
0.163\end{array}$ & $\begin{array}{c}984 \\
-457.97 \\
0.113\end{array}$ & $\begin{array}{c}336 \\
-206.87 \\
0.06\end{array}$ & $\begin{array}{c}648 \\
-241.28 \\
0.101\end{array}$ \\
\hline
\end{tabular}

Notes: Other regressors include head of household, age and age squared, indicators for educational level, married, household size, number of children below 14, number of earning household members, a set of 5 regional indicators and controls for household wealth. *, **, *** indicate significance at the 10 per cent, 5 per cent, and 1 per cent levels, respectively. 
Table 9

Transition to Employment

5 Nearest Neighbors Matching Estimates-Restricted to Common Support (Standard Errors)

\begin{tabular}{|l|c|c|c|}
\hline $\begin{array}{l}\text { Transition between May } 2002 \text { and May } \\
2003\end{array}$ & $\begin{array}{c}(1) \\
\text { Full Sample }\end{array}$ & $\begin{array}{c}(2) \\
\text { Full Sample } \\
\text { Male }\end{array}$ & $\begin{array}{c}(3) \\
\text { Full Sample } \\
\text { Female }\end{array}$ \\
\hline Effect of Unemployment Assistance & $-0.323^{* * *}$ & $-0.234^{* * *}$ & $-0.370^{* * *}$ \\
& $(0.048)$ & $(0.063)$ & $(0.071)$ \\
\hline$N$ & 1116 & 693 & 402 \\
\hline Transition between May 2002 and May & Restricted to & Restricted to & Restricted to \\
2003 & UA and & UA and & UAnd \\
& Applicants & Applicants & Applicants \\
\hline Effect of Unemployment Assistance & $-0.349^{* * *}$ & $-0.168^{*}$ & $-0.431^{* * *}$ \\
& $(0.078)$ & $(0.100)$ & $(0.071)$ \\
\hline$N$ & 340 & 131 & 176 \\
\hline Transition between October 2002 and & Full Sample & Full Sample & Full Sample \\
May 2003 & & Male & Female \\
\hline Effect of Unemployment Assistance & $-0.382^{* * *}$ & $-0.305^{* * *}$ & $-0.369^{* * *}$ \\
& $(0.035)$ & $(0.039)$ & $(0.055)$ \\
\hline$N$ & 2415 & 1299 & 1115 \\
\hline Transition between October 2002 and & Restricted to & Restricted to & Restricted to \\
May 2003 & UA and & UA and & UA and \\
& Applicants & Applicants & Applicants \\
\hline Effect of Unemployment Assistance & $-0.369^{* * *}$ & $-0.262^{* * *}$ & $-0.411^{* * *}$ \\
& $(0.065)$ & $(0.085)$ & $(0.094)$ \\
\hline$N$ & 947 & 336 & 604 \\
\hline
\end{tabular}

Notes: Propensity scores were obtained from a logit regression of Plan Jefes on head of household, age and age squared, indicators for educational level, married, household size, number of children below 14, number of earning household members, a set of 5 regional indicators, and controls for household wealth. *,**,*** indicate significance at the 10 per cent, 5 per cent, and 1 per cent levels, respectively. Estimates based on kernel matching displayed a similar pattern. 


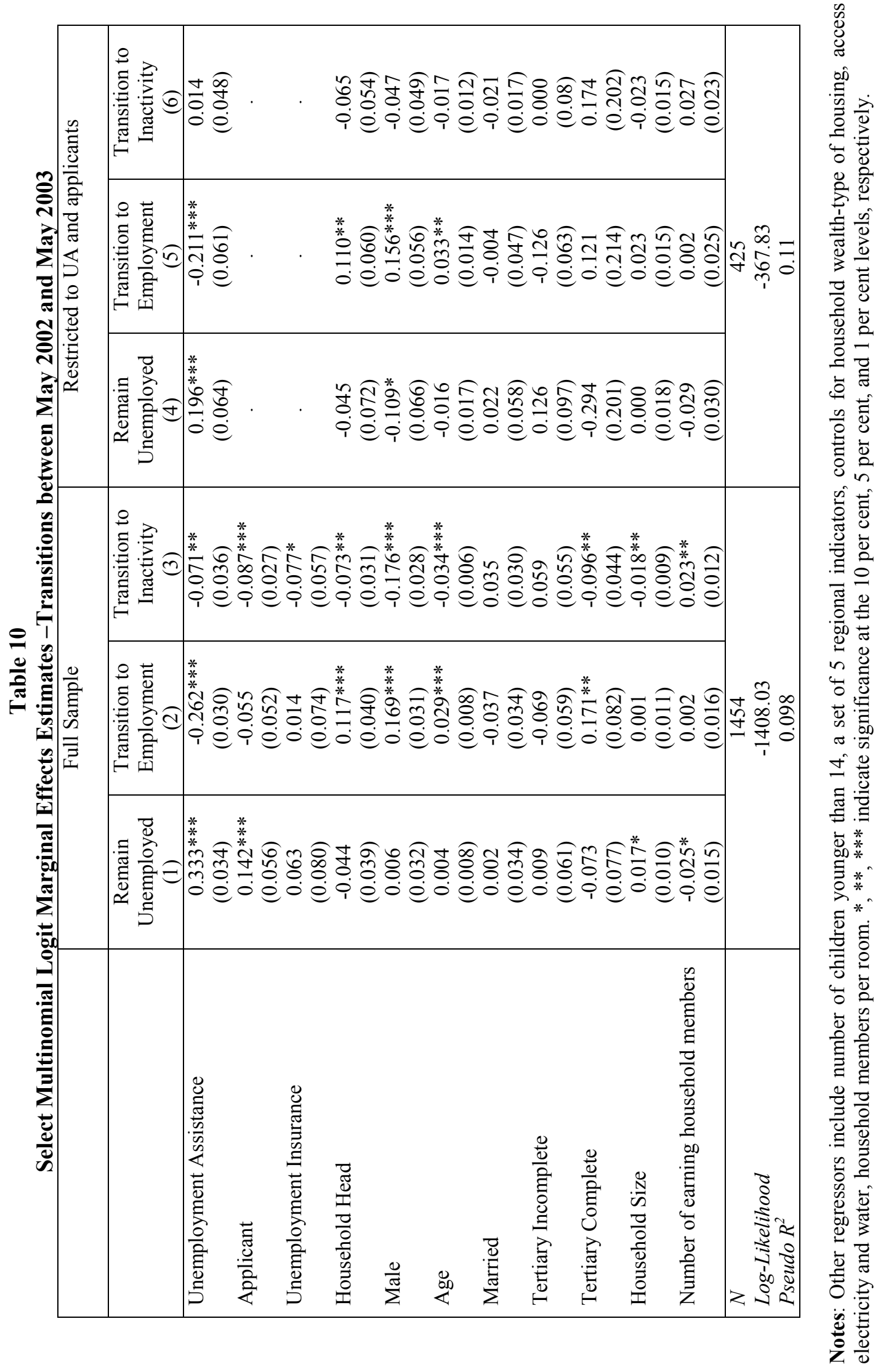



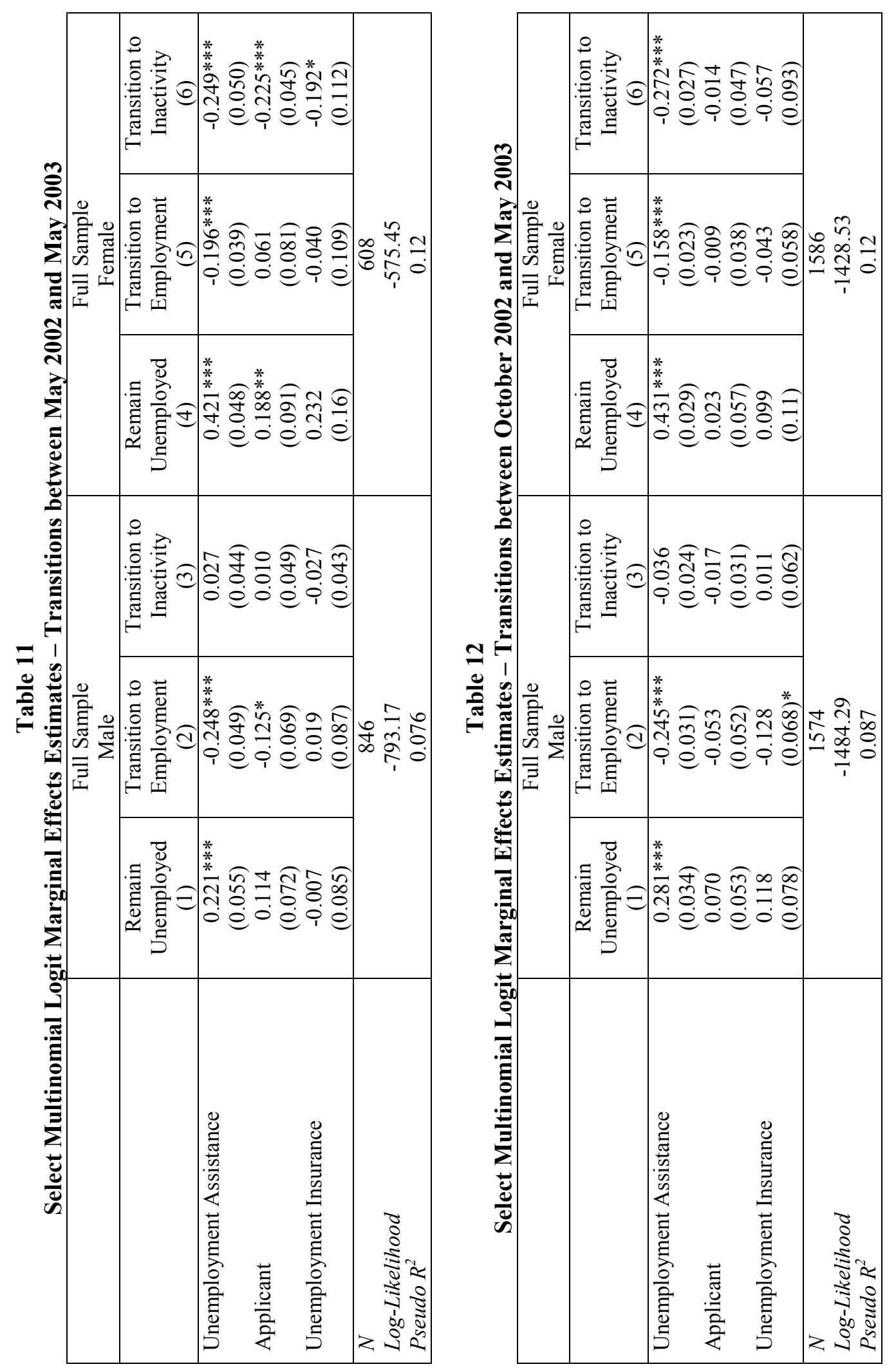

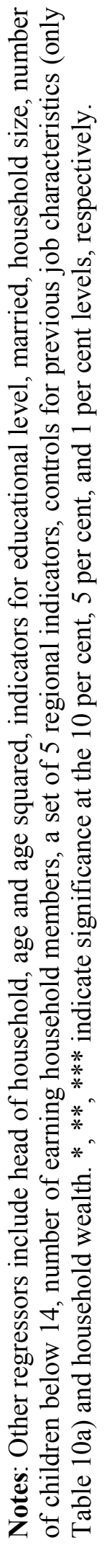




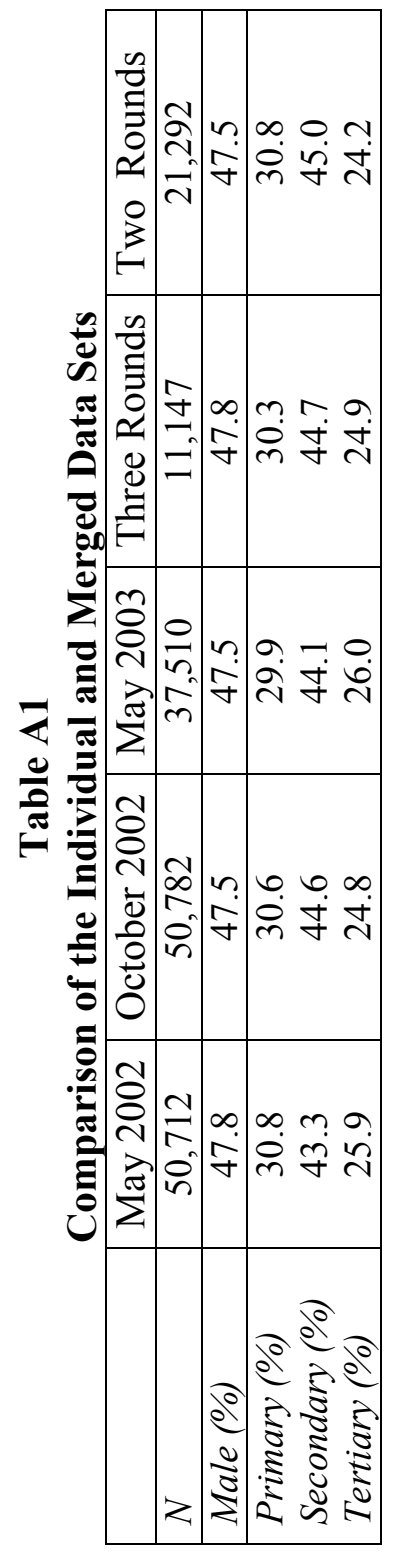




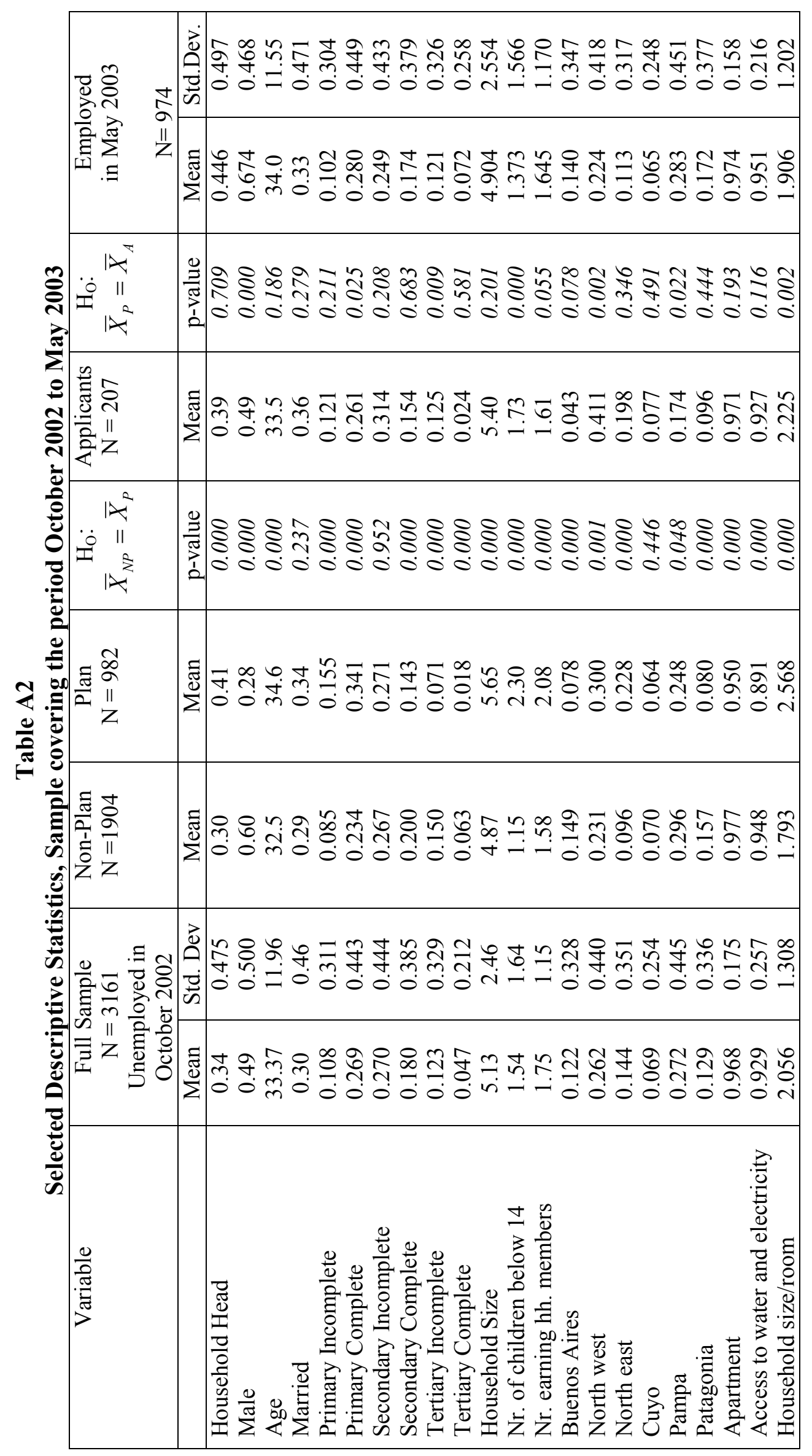




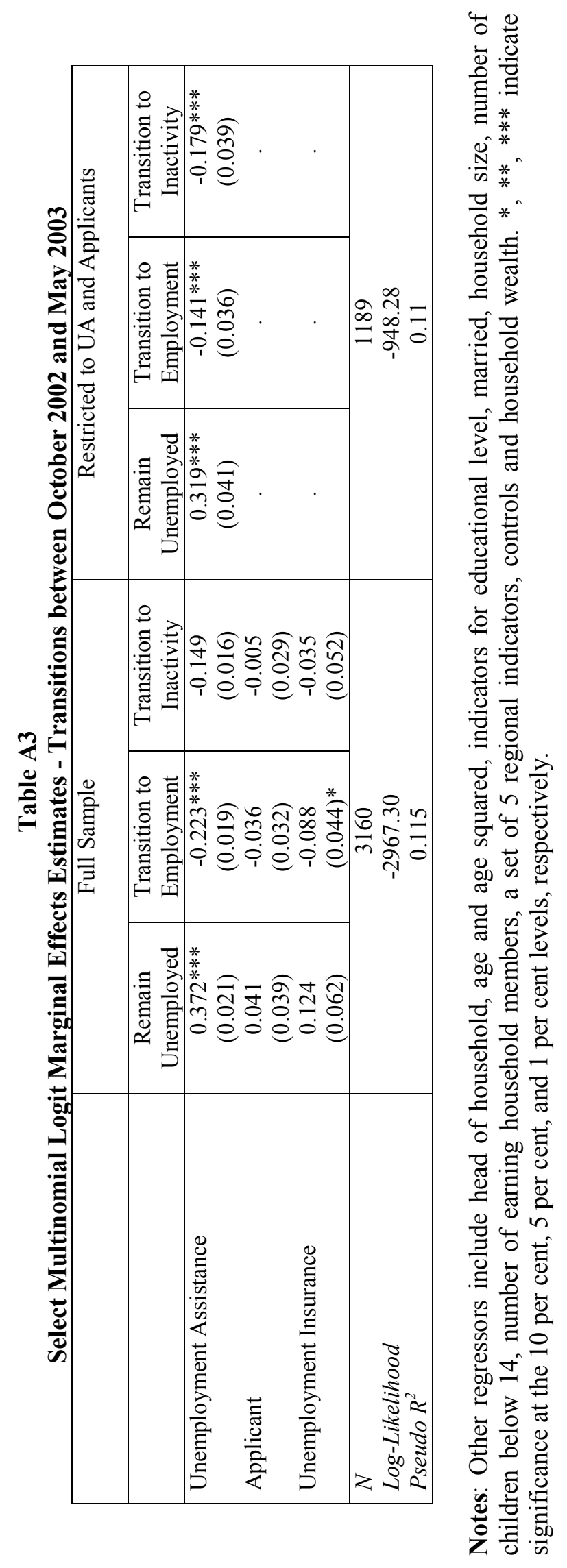


Table A4

Selection Corrected Probit Marginal Effects Estimates

Transition to Employment between October 2002 and May 2003

\begin{tabular}{|l|c|c|c|}
\hline \multicolumn{4}{|c|}{ (Standard Errors) } \\
& $\begin{array}{c}(1) \\
\text { Vuriable } \\
\text { Total }\end{array}$ & $\begin{array}{c}(2) \\
\text { Full Sample } \\
\text { Male }\end{array}$ & $\begin{array}{c}\text { Full Sample } \\
\text { Female }\end{array}$ \\
\hline Unemployment Assistance & $-0.410^{* * *}$ & $-0.389^{* * *}$ & $-0.307^{* * *}$ \\
& $(0.052)$ & $(0.105)$ & $(0.073)$ \\
& & & \\
Applicant & -0.047 & -0.067 & -0.019 \\
& $(0.041)$ & $(0.058)$ & $(0.056)$ \\
Unemployment Insurance & $-0.118^{*}$ & $-0.135^{*}$ & -0.067 \\
& $(0.058)$ & $(0.078)$ & $(0.085)$ \\
Generalised Residual & 0.062 & 0.075 & -0.025 \\
& $(0.043)$ & $(0.081)$ & $(0.050)$ \\
\hline Nog likelihood & 2418 & 1303 & 1115 \\
Pseudo $R^{2}$ & -1437.15 & -861.47 & -561.77 \\
& 0.118 & 0.05 & 0.156 \\
\hline
\end{tabular}

Notes: Other regressors include head of household, age and age squared, indicators for educational level, married, and a set of 5 regional indicators. The generalised residual is obtained from a first-step probit regression of program participation on observed characteristics. Identification is achieved by including variables that capture household wealth (type of housing, access to electricity and water, household members per room) and number of children below the age of 14, family size and number of earning household members only in the first-step equation. $*, * *, * * *$ indicate significance at the 10 per cent, 5 per cent, and 1 per cent levels, respectively. 
Distribution of propensity scores for Jefes participants (treated) and applicants (untreated) Panel data covering the period May 2002 to May 2003

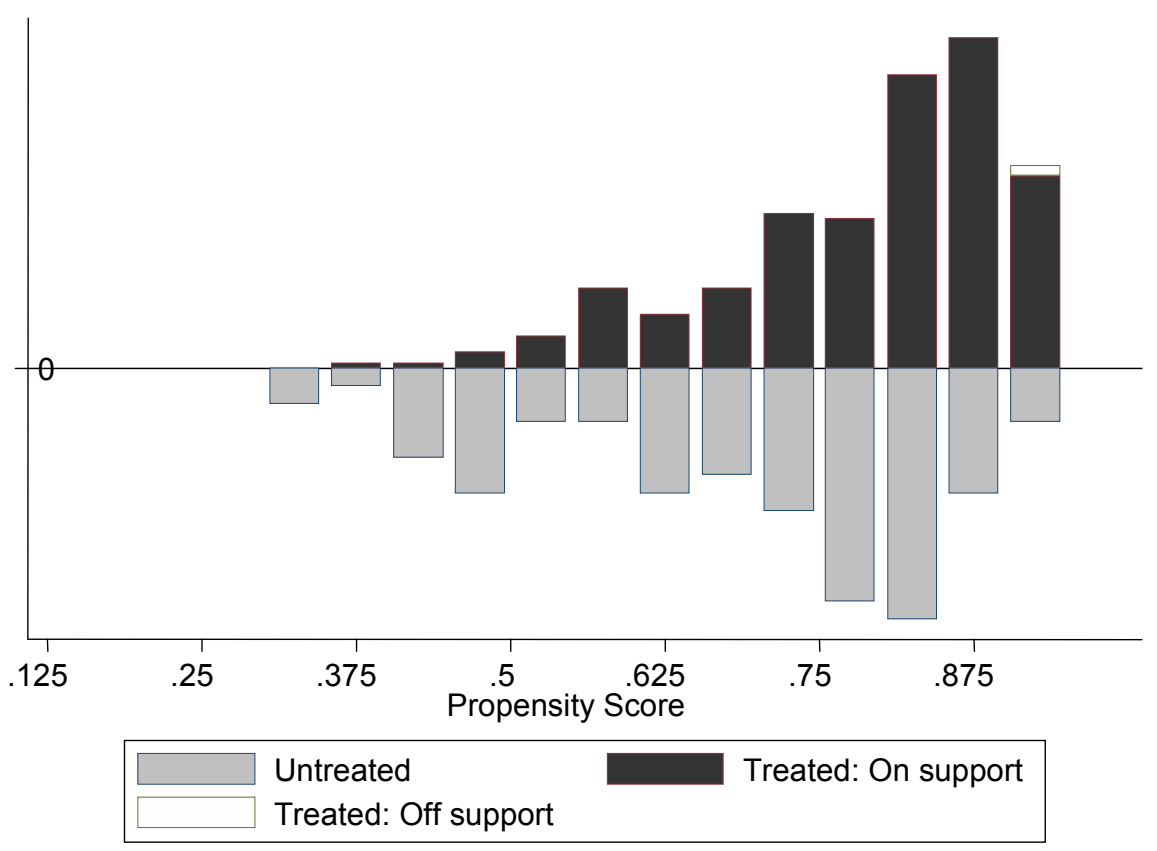

Figure 2

Distribution of propensity scores for Jefes participants (treated) and applicants (untreated)

Panel data covering the period October 2002 to May 2003

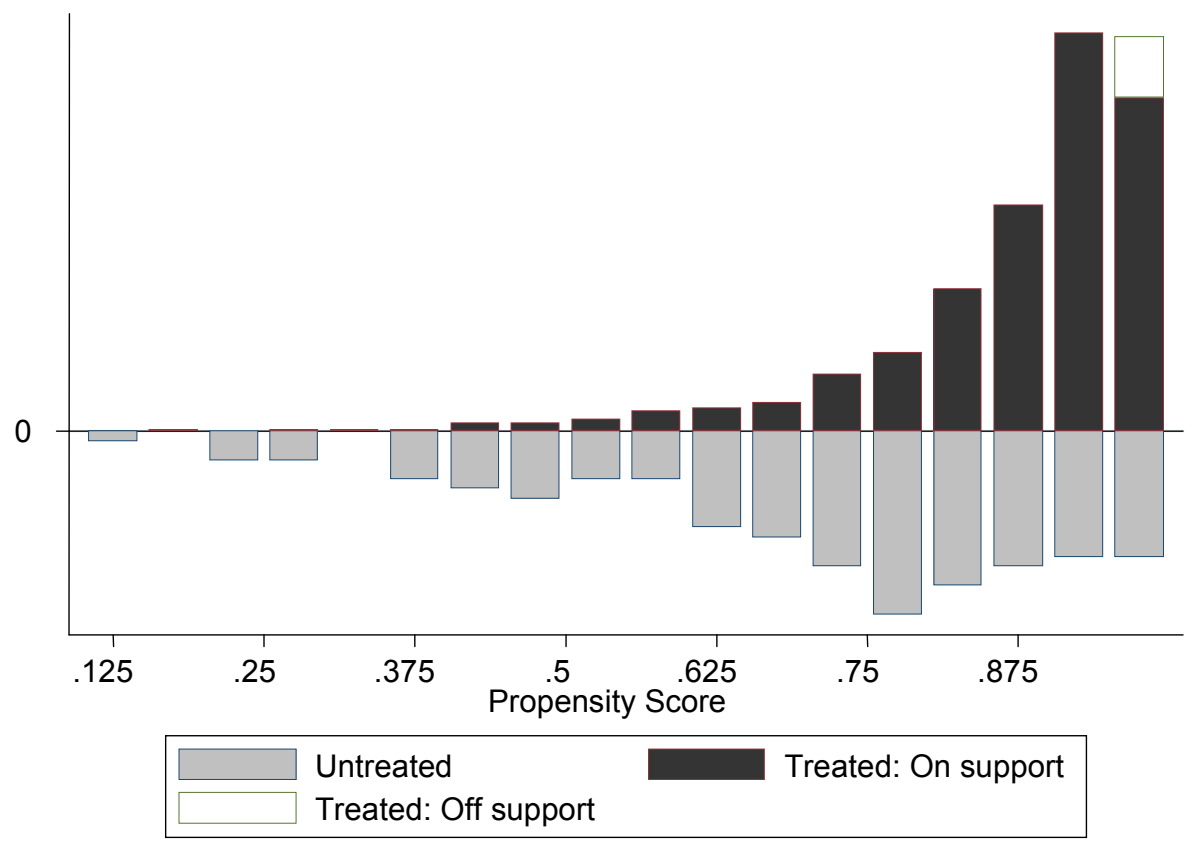

